ARTICLE

\title{
Single-pass transformation of syngas into ethanol with high selectivity by triple tandem catalysis
}

Jincan Kang ${ }^{1,2}$, Shun He ${ }^{1,2}$, Wei Zhou ${ }^{1,2}$, Zheng Shen ${ }^{1}$, Yangyang $\mathrm{Li}^{1}$, Mingshu Chen $\mathbb{1}^{1}$, Qinghong Zhang ${ }^{1 凶}$ \& Ye Wang (1) ${ }^{1 \times}$

Synthesis of ethanol from non-petroleum carbon resources via syngas (a mixture of $\mathrm{H}_{2}$ and $\mathrm{CO}$ ) is an important but challenging research target. The current conversion of syngas to ethanol suffers from low selectivity or multiple processes with high energy consumption. Here, we report a high-selective conversion of syngas into ethanol by a triple tandem catalysis. An efficient trifunctional tandem system composed of potassium-modified $\mathrm{ZnO}-\mathrm{ZrO}_{2}$, modified zeolite mordenite and $\mathrm{Pt}-\mathrm{Sn} / \mathrm{SiC}$ working compatibly in syngas stream in one reactor can afford ethanol with a selectivity of $90 \%$. We demonstrate that the $\mathrm{K}^{+}-\mathrm{ZnO}-\mathrm{ZrO}_{2}$ catalyses syngas conversion to methanol and the mordenite with eight-membered ring channels functions for methanol carbonylation to acetic acid, which is then hydrogenated to ethanol over the Pt-Sn/SiC catalyst. The present work offers an effective methodology leading to high selective conversion by decoupling a single-catalyst-based complicated and uncontrollable reaction into well-controlled multi-steps in tandem in one reactor.

\footnotetext{
${ }^{1}$ State Key Laboratory of Physical Chemistry of Solid Surfaces, Collaborative Innovation Center of Chemistry for Energy Materials, National Engineering Laboratory for Green Chemical Productions of Alcohols, Ethers and Esters, College of Chemistry and Chemical Engineering, Xiamen University, Xiamen 361005, China. ${ }^{2}$ These authors contributed equally: Jincan Kang, Shun He, Wei Zhou. ${ }^{凶}$ email: zhangqh@xmu.edu.cn; wangye@xmu.edu.cn
} 
S yngas $\left(\mathrm{H}_{2} / \mathrm{CO}\right)$, which can be produced from natural (shale) gas, coal, biomass, carbon-containing waste and carbon dioxide, is one of the most important platforms for utilization of non-petroleum resources to supply energy and chemical feedstocks. The depletion of crude oil and the growing demand for fuels and chemicals have stimulated recent research activities in syngas transformations ${ }^{1-3}$. As an ideal fuel additive, a promising hydrogen carrier and a versatile building-block for chemicals, fuels and polymers ${ }^{4,5}$, ethanol is one of the most attractive molecules that may be produced from syngas. The current production of ethanol relies on the fermentation of sugars, but this process suffers from the competition with food supply, the high energy consumption in product separation and purification, and the limited efficiency and ethanol selectivity ${ }^{6-8}$. The chemical synthesis of ethanol from various carbon resources via syngas represents one of the most promising approaches.

Many studies have been devoted to the direct conversion of syngas into ethanol with a single catalyst (Fig. 1, Route A) ${ }^{5,8-11}$. This reaction is complicated because of many elementary steps involved, which include $\mathrm{H}_{2}$ dissociation, $\mathrm{CO}$ dissociative and non-dissociative activation, formation of adsorbed $\mathrm{CO}, \mathrm{CH}_{x} \mathrm{O}$ and $\mathrm{CH}_{x}$ intermediates, $\mathrm{C}-\mathrm{C}$ coupling between different intermediates, and formation of products ${ }^{5,8,9,11}$. The multiple intermediates lead to different reaction channels, forming methane, methanol, $\mathrm{C}_{2+}$ hydrocarbons and $\mathrm{C}_{2+}$ oxygenates together with ethanol. The selective synthesis of ethanol requires the precise control of $\mathrm{C}-\mathrm{C}$ coupling between intermediates from $\mathrm{CO}$ dissociative and non-dissociative activation. The design of a single catalyst with different functionalities to enable only a single reaction channel is very difficult. Although much effort has been devoted to designing bi- or multi-component catalysts such as $\mathrm{Rh}-\mathrm{Mn}, \mathrm{Rh}-\mathrm{Fe}, \mathrm{Cu}-\mathrm{Co}$ and $\mathrm{Cu}-\mathrm{Fe}$ catalysts, the ethanol selectivity is lower than $60 \%$ even at limited CO conversions (Supplementary Table 1$)^{12-19}$.

Syngas can also be transformed into ethanol through indirect routes via methanol or dimethyl ether (DME) synthesis, followed by carbonylation with $\mathrm{CO}$ and subsequent hydrogenation of acetic acid or methyl acetate (Fig. 1, Routes B and C). The indirect routes suffer from multiple processes and energy-consuming product separation/purification in each process. The recently developed route via DME and methyl acetate (Fig. 1, Route C) is more cost-efficient and environmental friendly because of the use of halogen-free heterogeneous $\mathrm{H}$-form mordenite (H-MOR) zeolite to replace iodide-promoted $\mathrm{Rh}$ complex homogeneous catalyst for carbonylation 20,21 . However, the overall selectivity of ethanol is limited to $67 \%$ due to methanol formation in subsequent hydrogenation. The development of new routes for single-pass conversion of syngas to ethanol with high selectivity is very attractive but highly challenging.

Tandem catalysis, which can perform multi-step sequential reactions in a single reactor or one pot, has offered an opportunity to discover new catalytic processes with better efficiencies ${ }^{22-25}$. The conversion of syngas to $\mathrm{C}_{2}-\mathrm{C}_{4}$ olefins or aromatics beyond traditional Fischer-Tropsch synthesis has recently been achieved by designing bifunctional catalysts that work in tandem for $\mathrm{CO}$ hydrogenation to $\mathrm{CH}_{3} \mathrm{OH} / \mathrm{DME}$ or ketene intermediate and conversion of intermediate to target product ${ }^{26-30}$. Unlike uncontrollable chain growth on Fischer-Tropsch metal surfaces, the $\mathrm{C}-\mathrm{C}$ coupling in these systems occurs inside zeolite cages, where the confinement effect narrows the product distribution by shape selectivity. However, the high-selective synthesis of a specific product, in particular a $\mathrm{C}_{2+}$ oxygenate, by using the concept of shape selectivity is very challenging.

The decoupling of a complicated reaction with many reaction channels into controllable multi-steps would enable the control of reaction channel. Unlike the bifunctional catalysis using the shape selectivity of zeolite to control the product selectivity ${ }^{26-30}$, the present work aims at reaction channel-controlled $\mathrm{C}-\mathrm{C}$ coupling. Our idea is that the syngas reactant enables us to perform not only hydrogenation but also carbonylation, which produces a $\mathrm{C}_{2}$ oxygenate. A few recent studies have adopted this methodology for the synthesis of $\mathrm{C}_{2}$ oxygenates. We succeeded in synthesizing methyl acetate from syngas by tandem catalysis via DME intermediate $^{31}$. Although ethanol was obtained by using a threecomponent catalytic system composed of layer-by-layer $\mathrm{ZnAl}_{2} \mathrm{O}_{4}$, $\mathrm{H}-\mathrm{MOR}$ and $\mathrm{ZnAl}_{2} \mathrm{O}_{4}$, the selectivity of ethanol was only $\sim 50 \%$. A sandwich-configuration catalytic system composed of $\mathrm{CuZnO}$, $\mathrm{CuH}-\mathrm{MOR}$ and $\mathrm{CuZnO}_{x}$ was also reported for syngas conversion, but the ethanol selectivity was only $15 \%{ }^{32}$. The co-feeding of DME and syngas over dual-bed catalysts for DME carbonylation and methyl acetate hydrogenation provided ethanol with selectivity of $<50 \%{ }^{33-35}$.

Here, we report the design of new tandem catalytic systems with high ethanol selectivity (Fig. 1, Route D). We discovered that the integration of methanol synthesis, methanol carbonylation and acetic acid hydrogenation in tandem in one reactor could accomplish the selective conversion of syngas into ethanol with selectivity as high as $90 \%$. We demonstrate that the careful design of each catalyst to direct the reaction channel to the target intermediate or product, the interplay between the three steps and the compatibility of each catalyst in syngas stream are crucial to ethanol selectivity. The present work opens an avenue for the innovation of selective conversion route by decoupling an uncontrollable reaction, which has multiple elementary steps and

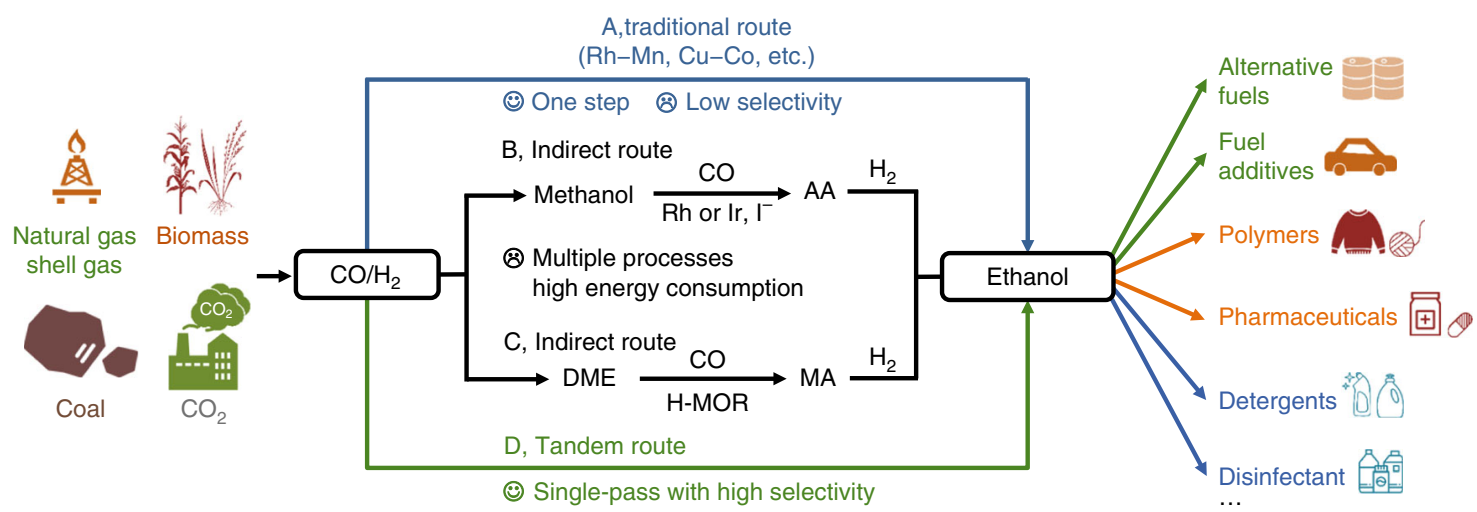

Fig. 1 Routes for conversion of syngas to ethanol. Route $A$, traditional and direct route based on a single catalyst. Route $B$, indirect route including three processes, i.e., methanol synthesis, methanol carbonylation with $\mathrm{CO}$ and acetic acid (AA) hydrogenation. Route $C$, indirect route including three processes, i.e., syngas to dimethyl ether (DME), DME carbonylation with $C O$ and methyl acetate (MA) hydrogenation. Route D, Tandem catalytic route of this work. 
many reaction channels, into well-controlled multi-steps with tandem catalysis.

\section{Results}

Composition and performance of tandem catalysts. Thermodynamic analyses reveal that all the three tandem steps, i.e., methanol synthesis, methanol carbonylation and acetic acid hydrogenation, are thermodynamically more feasible at lower temperatures (Supplementary Fig. 1). A higher temperature is particularly unfavourable to methanol synthesis. However, methanol carbonylation and acetic acid hydrogenation usually need to proceed at $500-600 \mathrm{~K}$ because of the kinetic requirement ${ }^{36,37}$. CO equilibrium conversions for ethanol synthesis via tandem catalysis were evaluated to be $38 \%$ and $12 \%$ at 550 and $600 \mathrm{~K}$, respectively, under a syngas $\left(\mathrm{H}_{2} / \mathrm{CO}=1\right)$ pressure of 5.0 $\mathrm{MPa}$ (Supplementary Fig. 1 and Supplementary Note 1). To match methanol carbonylation and acetic acid hydrogenation reactions, we first investigated catalytic behaviours of some typical metal oxides that are capable of catalysing syngas conversion to $\mathrm{CH}_{3} \mathrm{OH} / \mathrm{DME}$ at $500-600 \mathrm{~K}$. $\mathrm{ZnAl}_{2} \mathrm{O}_{4}, \mathrm{ZnGa}_{2} \mathrm{O}_{4}$ and $\mathrm{ZnCr}_{2} \mathrm{O}_{4}$ compounds with spinel structure were selective for DME formation (Fig. 2a). On the other hand, $\mathrm{ZnO}-\mathrm{ZrO}_{2}(\mathrm{Zn} / \mathrm{Zr}$ $=1: 8)$ and $\mathrm{ZrO}_{2}-\mathrm{In}_{2} \mathrm{O}_{3}(\mathrm{Zr} / \mathrm{In}=1: 2)$ composites showed higher $\mathrm{CH}_{3} \mathrm{OH}$ selectivity, but the formation of undesirable $\mathrm{CH}_{4}$ was serious over the $\mathrm{ZrO}_{2}-\mathrm{In}_{2} \mathrm{O}_{3}$ possibly because of its high hydrogenation ability ${ }^{38}$. The modification of the $\mathrm{ZnO}-\mathrm{ZrO}_{2}$ by $\mathrm{K}^{+}(\mathrm{K} /$ $\mathrm{Zn} / \mathrm{Zr}=0.07: 1: 8)$ further improved $\mathrm{CH}_{3} \mathrm{OH}$ selectivity to $93 \%$ (Fig. 2a). Over these metal oxides, $\mathrm{CO}_{2}$ was also formed, indicating the occurrence of water-gas shift (WGS) reaction caused by
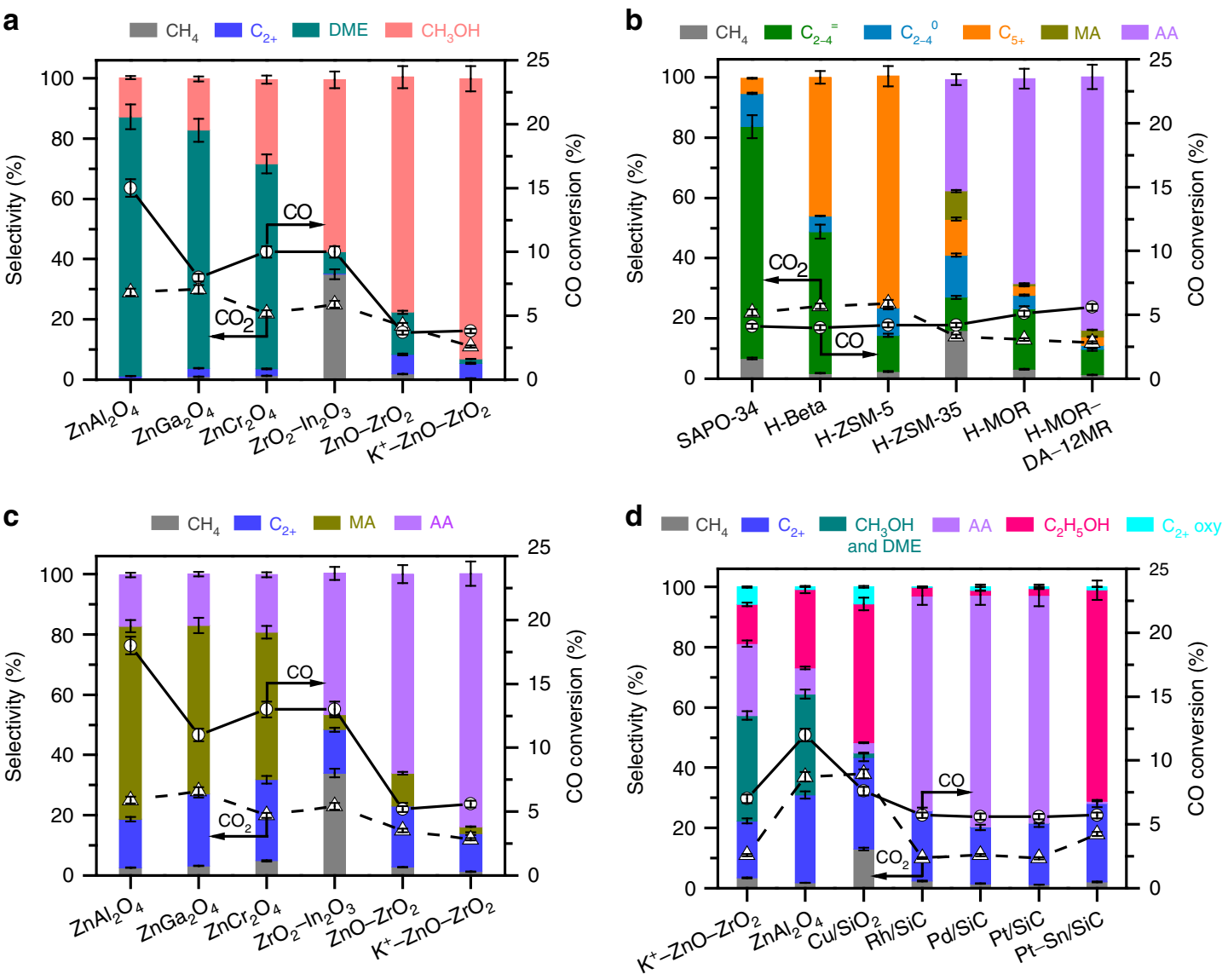

e

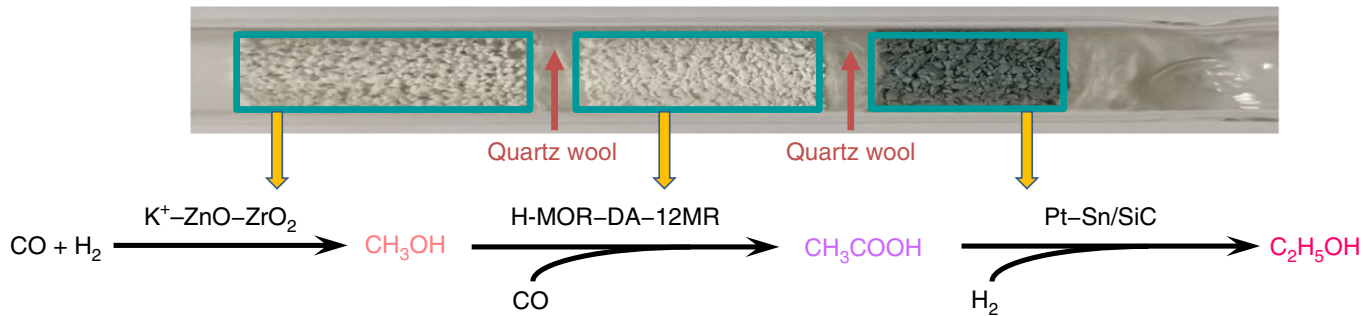

Fig. 2 Catalytic behaviours and reaction pathways. a Metal oxides alone. $\mathbf{b}$ Combinations of $\mathrm{K}^{+}-\mathrm{ZnO}-\mathrm{ZrO}_{2}$ and zeolites. $\mathbf{c}$ Combinations of metal oxides and $\mathrm{H}-\mathrm{MOR}-\mathrm{DA}-12 \mathrm{MR}$. d Combinations of $\mathrm{K}^{+}-\mathrm{ZnO}-\mathrm{ZrO}_{2}, \mathrm{H}-\mathrm{MOR}-\mathrm{DA}-12 \mathrm{MR}$ and hydrogenation catalysts. e Reaction pathways for direct synthesis of ethanol from syngas. $C_{2+}: C_{2+}$ hydrocarbons; DME: dimethyl ether; $C_{2-4}=: C_{2}-C_{4}$ olefins; $C_{2-4} 0: C_{2}-C_{4}$ paraffins; $C_{5+}$ : $C_{5+}$ hydrocarbons; MA: methyl acetate; $A A$ : acetic acid; $C_{2+}$ oxy.: ethyl acetate and methyl acetate. Reaction conditions: weights of metal oxide, zeolite and hydrogenation catalyst $=0.66$, 0.66 and $0.66 \mathrm{~g} ; \mathrm{H}_{2} / \mathrm{CO}=1: 1 ; P=5.0 \mathrm{MPa} ; T=583 \mathrm{~K} ; F=25 \mathrm{~mL} \mathrm{~min}^{-1}$; time on stream, $20 \mathrm{~h}$. The selectivity was calculated on a molar carbon basis. Carbon balances were $95-99 \%$. The experiments in each case were performed for three times. The error bar represents the relative deviation, which is within $5 \%$. 
$\mathrm{H}_{2} \mathrm{O}$ formed during syngas conversions. The $\mathrm{CO}_{2}$ selectivity, which was calculated separately from the hydrogenation products, decreased in the sequence of $\mathrm{ZnGa}_{2} \mathrm{O}_{4}>\mathrm{ZnAl}_{2} \mathrm{O}_{4}>$ $\mathrm{ZrO}_{2}-\mathrm{In}_{2} \mathrm{O}_{3}>\mathrm{ZnCr}_{2} \mathrm{O}_{4}>\mathrm{ZnO}-\mathrm{ZrO}_{2}>\mathrm{K}^{+}-\mathrm{ZnO}-\mathrm{ZrO}_{2}$.

The integration of the $\mathrm{K}^{+}-\mathrm{ZnO}-\mathrm{ZrO}_{2}$ and a zeolite in tandem separated by quartz wool (denoted as $\mathrm{K}^{+}-\mathrm{ZnO}-\mathrm{ZrO}_{2} \mid$ zeolite) resulted in different products depending on zeolite topology (Fig. 2b). Lower olefins were formed with a selectivity of $\sim 80 \%$ using $\mathrm{K}^{+}-\mathrm{ZnO}-\mathrm{ZrO}_{2} \mid$ SAPO-34 combination, in agreement with the fact that SAPO-34 is an excellent methanol-to-olefins (MTO) catalyst $^{39}$. Higher hydrocarbons with carbon numbers of $\geq 5$ $\left(\mathrm{C}_{5+}\right)$ were formed with considerable selectivity using $\mathrm{K}^{+}-\mathrm{ZnO}-\mathrm{ZrO}_{2} \mid \mathrm{H}$-beta and $\mathrm{K}^{+}-\mathrm{ZnO}-\mathrm{ZrO}_{2} \mid \mathrm{H}-\mathrm{ZSM}-5$, also coinciding with the effect of zeolite topology on product distribution in methanol-to-hydrocarbons (MTH) reaction ${ }^{40}$. Uniquely, besides hydrocarbons, acetic acid was formed by combining $\mathrm{H}-\mathrm{ZSM}-35$ or $\mathrm{H}-\mathrm{MOR}$ with the $\mathrm{K}^{+}-\mathrm{ZnO}-\mathrm{ZrO}_{2}$ (Fig. 2b). It is known that H-MOR and H-ZSM-35, both of which possess eight-membered-ring (8-MR) channels, are capable of catalysing the carbonylation of DME with $\mathrm{CO}$ to methyl acetate at $423-473 \mathrm{~K}^{21,41,42}$. The Brønsted acid sites located inside the 8-MR channels are proposed for carbonylation through the Koch-type reaction, while those inside the $12-\mathrm{MR}$ or $10-\mathrm{MR}$ channels are responsible for the formation of hydrocarbons and coke $\mathrm{c}^{21,41-43}$. Although H-MOR is known to be also capable of catalysing the carbonylation of methanol at $500-600 \mathrm{~K}^{36}$, the catalyst requirement for methanol carbonylation is less understood. We found that the selective removal of framework $\mathrm{Al}$ in the 12-MR channels (denoted as H-MOR-DA-12MR) increased acetic acid selectivity to $84 \%$ (Fig. 2b). The combination of $\mathrm{K}^{+}-\mathrm{ZnO}-\mathrm{ZrO}_{2} \mid \mathrm{H}-\mathrm{MOR}-\mathrm{DA}-12 \mathrm{MR}$ showed the lowest $\mathrm{CO}_{2}$ selectivity. When the $\mathrm{ZnAl}_{2} \mathrm{O}_{4}, \mathrm{ZnGa}_{2} \mathrm{O}_{4}$ or $\mathrm{ZnCr}_{2} \mathrm{O}_{4}$, which catalysed DME formation, was integrated with the $\mathrm{H}$ MOR-DA-12MR, methyl acetate was formed as the major product (Fig. 2c), indicating the occurrence of DME carbonylation over the $\mathrm{H}-\mathrm{MOR}-\mathrm{DA}-12 \mathrm{MR}$. The change in $\mathrm{CO}_{2}$ selectivity with metal oxide for the metal oxide $/ \mathrm{H}-\mathrm{MOR}-\mathrm{DA}-12 \mathrm{MR}$ combination showed a similar trend to that for metal oxides alone. The comparison of Figs. $2 \mathrm{a}$ and $\mathrm{c}$ demonstrates that the final product can be directed by the intermediate in tandem system; $\mathrm{CH}_{3} \mathrm{OH}$ as an intermediate leads to acetic acid, while DME results in methyl acetate. Rh-based catalysts as well as an indirect route integrated by multiple reaction processes via methanol, DME and methyl acetate have been exploited for the conversion of syngas into acetic acid (Supplementary Table 2). The present $\mathrm{K}^{+}-\mathrm{ZnO}-\mathrm{ZrO}_{2} \mid \mathrm{H}-\mathrm{MOR}-\mathrm{DA}-12 \mathrm{MR}$ system shows significantly higher acetic acid selectivity than most of the Rhbased catalysts or the multi-process route.

The triple tandem system composed of $\mathrm{K}^{+}-\mathrm{ZnO}-\mathrm{ZrO}_{2} \mid \mathrm{H}-$ MOR-DA-12MR and a hydrogenation catalyst was designed for the conversion of syngas to ethanol. The use of metal oxides, i.e., $\mathrm{K}^{+}-\mathrm{ZnO}-\mathrm{ZrO}_{2}$ and $\mathrm{ZnAl}_{2} \mathrm{O}_{4}$, as the hydrogenation catalyst in the downstream only showed low ethanol selectivity (Fig. 2d). Methanol and DME were also formed, suggesting that the metal oxide catalysed the further conversion of remaining syngas. The use of $\mathrm{Cu} / \mathrm{SiO}_{2}$ provided a higher ethanol selectivity (46\%), but $\mathrm{CH}_{4}$ was formed with a considerable selectivity (13\%) at $583 \mathrm{~K}$. The ethanol selectivity became lower at lower temperatures in the case of $\mathrm{Cu} / \mathrm{SiO}_{2}$ because of the decreased efficiency of acetic acid hydrogenation (Supplementary Table 3). It is unexpected that the $\mathrm{Rh} / \mathrm{SiC}, \mathrm{Pd} / \mathrm{SiC}$ and $\mathrm{Pt} / \mathrm{SiC}$ were almost inactive for the hydrogenation of acetic acid in the triple tandem system, although supported noble metals were reported to catalyse this reaction $^{37}$. Interestingly, the modification of $\mathrm{Pt} / \mathrm{SiC}$ by $\mathrm{Sn}$ completely changed the major product in the triple tandem system from acetic acid to ethanol (Fig. 2d). The ethanol selectivity increased with the content of $\mathrm{Sn}$ in the $\mathrm{Pt}-\mathrm{Sn} / \mathrm{SiC}$ catalyst and was saturated at $70 \%$ at $583 \mathrm{~K}$ when the $\mathrm{Sn}$ content reached $1.2 \mathrm{wt} \%$ (Supplementary Table 4). $\mathrm{C}_{2}-\mathrm{C}_{4}$ olefins and $\mathrm{CO}_{2}$ were the major by-products, and their selectivities were $16 \%$ and $18 \%$, respectively. The increase of $\mathrm{Pt}$ loading in the $\mathrm{Pt}-\mathrm{Sn} / \mathrm{SiC}$ from 0.5 to $1.0 \mathrm{wt} \%$ slightly increased ethanol selectivity, but a higher Pt loading (>1.2 wt\%) would promote the WGS reaction to form more $\mathrm{CO}_{2}$ and the hydrogenation of lower olefins to paraffins (Supplementary Table 5). The results in Fig. 2a-d clearly demonstrate that the conversion of syngas to ethanol proceeds through a tandem mechanism via methanol and acetic acid intermediates (Fig. 2e).

The catalytic performance depends on the ratio of amounts of the three catalyst components. The increase in the amount of $\mathrm{K}^{+}-\mathrm{ZnO}-\mathrm{ZrO}_{2}$ from 0.66 to $1.00 \mathrm{~g}$ in the $\mathrm{K}^{+}-\mathrm{ZnO}-\mathrm{ZrO}_{2} \mid \mathrm{H}-$ MOR-DA-12MR $\mid \mathrm{Pt}-\mathrm{Sn} / \mathrm{SiC}$ increased CO conversion from 5.7 to $8.4 \%$ and the ethanol selectivity decreased only slightly to $68 \%$ at $583 \mathrm{~K}$ (Supplementary Table 6). A further increase in the amount of $\mathrm{K}^{+}-\mathrm{ZnO}-\mathrm{ZrO}_{2}$ to $1.50 \mathrm{~g}$ significantly decreased the ethanol selectivity. The increase in the amount of H-MOR-DA-12MR slightly improved the CO conversion and ethanol selectivity. The amount of $\mathrm{Pt}-\mathrm{Sn} / \mathrm{SiC}$ did not affect $\mathrm{CO}$ conversion, but a sufficient amount of $\mathrm{Pt}-\mathrm{Sn} / \mathrm{SiC}$ was required to keep ethanol selectivity high. We obtained a $9.7 \%$ CO conversion at ethanol selectivity of $64 \%$.

Structural characterizations of tandem catalysts. X-ray diffraction (XRD) measurements showed that only tetragonal $\mathrm{ZrO}_{2}$ and cubic $\mathrm{In}_{2} \mathrm{O}_{3}$ crystalline phases were observed in the $\mathrm{ZnO}-\mathrm{ZrO}_{2}$ $(\mathrm{Zn} / \mathrm{Zr}=1: 8)$ and $\mathrm{ZrO}_{2}-\mathrm{In}_{2} \mathrm{O}_{3}(\mathrm{Zr} / \mathrm{In}=1: 2)$ catalysts, respectively, whereas spinel-structured compounds were formed for the $\mathrm{ZnAl}_{2} \mathrm{O}_{4}, \mathrm{ZnGa}_{2} \mathrm{O}_{4}$ and $\mathrm{ZnCr}_{2} \mathrm{O}_{4}$ (Supplementary Fig. 2a). Tetragonal $\mathrm{ZrO}_{2}$ was also the sole phase in the $\mathrm{K}^{+}-\mathrm{ZnO}-\mathrm{ZrO}_{2}$ catalyst. The mean size of $\mathrm{K}^{+}-\mathrm{ZnO}-\mathrm{ZrO}_{2}$ particles estimated from transmission electron microscopy (TEM) was $9.1 \mathrm{~nm}$ (Fig. 3a). High-resolution TEM (HRTEM) micrographs for this sample showed the lattice fringes that could only be attributed to tetragonal $\mathrm{ZrO}_{2}\{011\}$ facet (Fig. 3b). These results suggest that $\mathrm{ZnO}$ was highly dispersed inside the lattice of $\mathrm{ZrO}_{2}$ to form solid solution, and this phenomenon was also reported previously 30,44 .

Ammonia temperature-programmed desorption $\left(\mathrm{NH}_{3}-\mathrm{TPD}\right)$ indicated the existence of acid sites on our metal oxides (Supplementary Fig. 2b). The density of acid sites decreased in the order of $\mathrm{ZnAl}_{2} \mathrm{O}_{4}>\mathrm{ZnGa}_{2} \mathrm{O}_{4}>\mathrm{ZnCr}_{2} \mathrm{O}_{4}>\mathrm{ZnO}-\mathrm{ZrO}_{2}>$ $\mathrm{ZrO}_{2}-\mathrm{In}_{2} \mathrm{O}_{3}>\mathrm{K}^{+}-\mathrm{ZnO}-\mathrm{ZrO}_{2}$. Pyridine-adsorbed Fourier-transform infrared (FT-IR) measurements suggested that Lewis acid sites existed on these metal oxides (Supplementary Fig. 2c) and the density of Lewis acid sites decreased in a trend similar to that from $\mathrm{NH}_{3}$-TPD. This agrees well with the order of increase in $\mathrm{CH}_{3} \mathrm{OH}$ selectivity and that of decrease in DME selectivity (Fig. 2a). Thus, the acidity of metal oxides influences the product selectivity in syngas conversions by catalysing the dehydration of $\mathrm{CH}_{3} \mathrm{OH}$ to DME. The modification of $\mathrm{ZnO}-\mathrm{ZrO}_{2}$ with $\mathrm{K}^{+}$ decreases the acidity, thus improving $\mathrm{CH}_{3} \mathrm{OH}$ selectivity.

Oxygen vacancy sites on $\mathrm{ZrO}_{2}$ surfaces have been proposed to account for $\mathrm{CO}$ activation ${ }^{45}$. Our electron paramagnetic resonance (EPR) spectroscopy measurements showed a signal at $g$ value of 2.003 (Supplementary Fig. 3), which could be attributed to oxygen vacancies over $\mathrm{ZrO}_{2}$-based metal oxides ${ }^{46}$. The incorporation of $\mathrm{ZnO}$ into $\mathrm{ZrO}_{2}$ to form solid solution enhanced the signal at $g$ value of 2.003 and thus the generation of oxygen vacancies over both $\mathrm{ZnO}-\mathrm{ZrO}_{2}$ and $\mathrm{K}^{+}-\mathrm{ZnO}-\mathrm{ZrO}_{2}$ samples. We believe that the increased density of oxygen vacancy sites favours the activation of $\mathrm{CO}$ as well as $\mathrm{H}_{2}{ }^{30,45,47}$.

The H-MOR-DA-12MR has been characterized by ${ }^{23} \mathrm{Na},{ }^{27} \mathrm{Al}$ and ${ }^{1} \mathrm{H}$ magic spinning nuclear magnetic resonance (MAS NMR) 

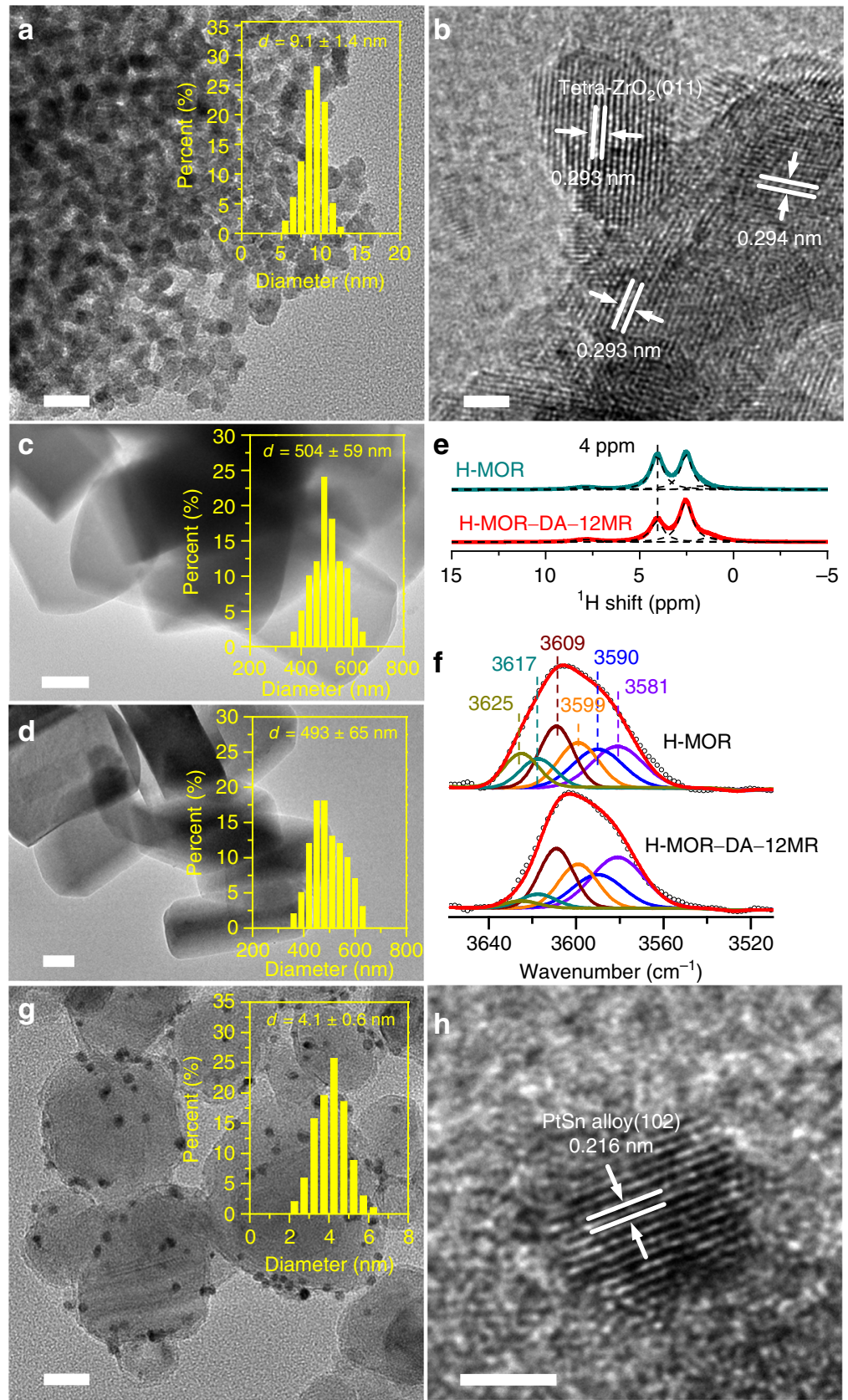

Fig. 3 Characterization of tandem catalysts. a TEM micrograph for $\mathrm{K}^{+}-\mathrm{ZnO}-\mathrm{ZrO}_{2}$ particles with particle size distribution. Scale bar: $20 \mathrm{~nm}$. b HRTEM micrograph for $\mathrm{K}^{+}-\mathrm{ZnO}-\mathrm{ZrO}_{2}$ particles. Scale bar: $2 \mathrm{~nm}$. c TEM micrograph for $\mathrm{H}-\mathrm{MOR}$ with particle size distribution. Scale bar: $100 \mathrm{~nm}$. d TEM micrograph for H-MOR-DA-12MR with particle size distribution. Scale bar: $100 \mathrm{~nm}$. e ${ }^{1} \mathrm{H}$ MAS NMR for H-MOR and H-MOR-DA-12MR zeolites. The peak at 4.0 ppm can be attributed to the Brønsted acid site. $\mathbf{f} \mathrm{FT}-\mathrm{IR}$ spectra of H-MOR and H-MOR-DA-12MR zeolites. Assignments of deconvoluted bands: 3625,3617 and $3609 \mathrm{~cm}^{-1}$ : Brønsted acid sites in 12-MR; $3599 \mathrm{~cm}^{-1}$ : Brønsted acid sites in intersections between 8-MR and 12-MR; 3590 and $3581 \mathrm{~cm}^{-1}:$ Brønsted acid sites in 8-MR. g TEM micrograph for Pt-Sn/SiC with particle size distribution. Scale bar: $20 \mathrm{~nm}$. h HRTEM micrograph for a Pt-Sn particle. Scale bar: $2 \mathrm{~nm}$.

spectroscopic studies. This sample was prepared by exchanging of $\mathrm{Na}^{+}$into pyridine-adsorbed H-MOR, removal of pyridine at 873 $\mathrm{K}$ and subsequent steam treatment at $723 \mathrm{~K}$, followed by ionexchanging with $\mathrm{NH}_{4}{ }^{+}$and calcination to remove $\mathrm{Na}^{+}$cations ${ }^{43}$. Both XRD (Supplementary Fig. 4a) and TEM (Figs. 3c and d) confirmed that the crystalline structure and morphology of $\mathrm{H}$ MOR were not changed. The $\mathrm{Na}^{+}$cations are expected to be mainly located in the 8-MR channel, where pyridine cannot enter. This was confirmed by ${ }^{23} \mathrm{Na}$ MAS NMR measurements, which could discriminate $\mathrm{Na}^{+}$cations in different locations ${ }^{48}$, and the result showed that $\mathrm{Na}^{+}$mainly remained in 8-MR channels after steam treatment at $723 \mathrm{~K}$ (Supplementary Fig. 5). The $\mathrm{Al}$ species with $\mathrm{Na}^{+}$in the ion-exchanging position are more robust toward steam treatment, and thus the $\mathrm{Al}$ species in 12-MR channels are more prone to dealumination during steam treatment. ${ }^{27} \mathrm{Al}$ (Supplementary Fig. 6) and ${ }^{1} \mathrm{H}$ MAS NMR (Fig. 3e) results suggest the removal of framework $\mathrm{Al}$ species and Brønsted acid sites (Fig. 3e ${ }^{49,50}$. Pyridine-adsorbed FT-IR studies showed significant decreases in intensities of IR bands ascribed to acid sites after steam treatment (Supplementary Fig. $4 \mathrm{~b}$ ), suggesting the occurrence of dealumination in 12-MR channels, because pyridine can only enter the 12-MR channel. FT-IR measurements in a range of $3540-3640 \mathrm{~cm}^{-1}$ also confirmed the partial removal of $\mathrm{OH}$ groups related to Brønsted acid sites in 12-MR channels 
(Fig. 3f). The combination of the ${ }^{1} \mathrm{H}$ MAS NMR result, which could provide information of the total amount of Brønsted acid sites, and the deconvolution result of IR bands belonging to $\mathrm{OH}$ groups allowed us to estimate the amounts of Brønsted acid sites in 8-MR and 12-MR channels as well as in the intersection between the two channels ${ }^{51,52}$. After dealumination, about $57 \%$ of Brønsted acid sites in 12-MR channels were removed, whereas $89 \%$ of Brønsted acid sites in 8 -MR channels were retained (Supplementary Table 7). We believe that the selective removal of Brønsted acid sites in 12-MR channels is the main reason for the enhancement in acetic acid selectivity by using the $\mathrm{H}$ MOR-DA-12MR (Fig. 2b).

TEM measurements for the $\mathrm{Pt} / \mathrm{SiC}$ and $\mathrm{Pt}-\mathrm{Sn} / \mathrm{SiC}$ catalysts showed that $\mathrm{Pt}$ or $\mathrm{Pt}-\mathrm{Sn}$ nanoparticles were uniformly dispersed on $\mathrm{SiC}$ support and the mean size of Pt particles decreased in the presence of Sn (Supplementary Fig. 7). The mean size of $\mathrm{Pt}$ particles was $4.1 \mathrm{~nm}$ in the $\mathrm{Pt}-\mathrm{Sn} / \mathrm{SiC}$ with a Sn content of $1.2 \mathrm{wt} \%$ (Fig. 3g). Line-scan energy-dispersive X-ray spectroscopy (EDS) (Supplementary Fig. 8) and HRTEM measurements (Fig. 3h and Supplementary Fig. 9) indicated the formation of Pt-Sn alloy. Quasi in situ X-ray photoelectron spectroscopy (XPS) studies showed that the binding energy of $\mathrm{Pt} 4 \mathrm{f}_{7 / 2}$ was $70.9-71.0 \mathrm{eV}$ for the $\mathrm{Pt} / \mathrm{SiC}$ catalyst after either $\mathrm{N}_{2}$ pretreatment at $673 \mathrm{~K}$ or syngas $\left(\mathrm{H}_{2} / \mathrm{CO}=1\right)$ pretreatment at $583 \mathrm{~K}$, indicating that $\mathrm{Pt}$ on this catalyst was in metallic state (Supplementary Fig. 10a) ${ }^{53,54}$. The binding energy of Pt $4 \mathrm{f}_{7 / 2}$ shifted to $71.4-71.5 \mathrm{eV}$ for the Pt-Sn/
SiC catalyst, suggesting that $\mathrm{Pt}^{\delta+}$ also existed in the presence of $\mathrm{Sn}$. The broad $\mathrm{Sn} 3 \mathrm{~d}$ spectrum for the $\mathrm{Pt}-\mathrm{Sn} / \mathrm{SiC}$ catalyst after either $\mathrm{N}_{2}$ or syngas pretreatment could be assigned to cationic $\mathrm{Sn}$ species $\left(\mathrm{Sn}^{2+}\right.$ and/or $\left.\mathrm{Sn}^{4+}\right)$ and a small fraction of $\mathrm{Sn}^{0}$ (Supplementary Fig. 10b) ${ }^{54}$. The ability of CO chemisorption decreased significantly by modifying the $\mathrm{Pt} / \mathrm{SiC}$ with $\mathrm{Sn}$ (Supplementary Fig. 10c).

Reaction kinetics and stability. We found that the increase in reaction temperature increased $\mathrm{CO}$ conversion but decreased ethanol selectivity for the $\mathrm{K}^{+}-\mathrm{ZnO}-\mathrm{ZrO}_{2}|\mathrm{H}-\mathrm{MOR}-\mathrm{DA}-12 \mathrm{MR}| \mathrm{Pt}-\mathrm{Sn} /$ $\mathrm{SiC}$ system (Fig. 4a). The ethanol selectivity decreased more steeply at $>583 \mathrm{~K}$. This is because the selectivity of $\mathrm{CH}_{3} \mathrm{OH}$ decreased and those of $\mathrm{C}_{2+}$ hydrocarbons and $\mathrm{CO}_{2}$ increased significantly at $>583$ $\mathrm{K}$ over the $\mathrm{K}^{+}-\mathrm{ZnO}-\mathrm{ZrO}_{2}$ catalyst (Supplementary Fig. 11). The $\mathrm{CO}$ conversion over this catalyst did not increase significantly at high temperatures due to the thermodynamic limitation (Supplementary Fig. 1). The ethanol selectivity reached $90 \%$ and $81 \%$ at CO conversions of $0.7 \%$ and $4.0 \%$ at 503 and $543 \mathrm{~K}$, respectively (Fig. $4 \mathrm{a}$ ). The reaction with the triple tandem system was performed at $543 \mathrm{~K}$ for six times with catalyst from different batches, and the performance with CO conversion of $4.0 \pm 0.2 \%$ and ethanol selectivity of $81 \pm 4 \%$ could be well reproduced (Supplementary Fig. 12). To the best of our knowledge, such high ethanol selectivity has never been reported before in syngas conversions (Supplementary Table 1).
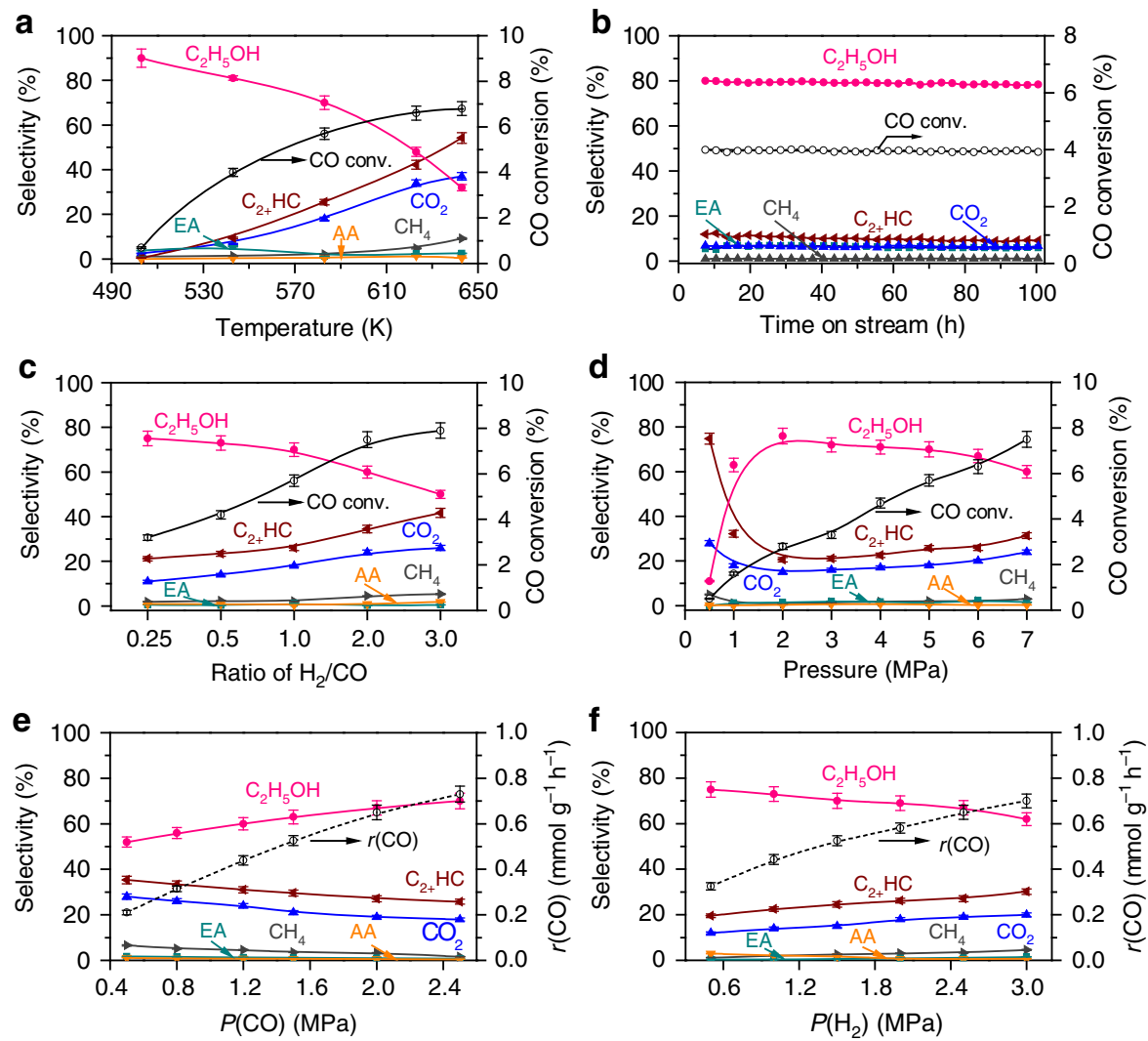

Fig. 4 Reaction kinetics for the triple tandem system. a Effect of reaction temperature. Reaction conditions: $\mathrm{H}_{2} / \mathrm{CO}=1: 1 ; P=5.0 \mathrm{MPa} ; F=25 \mathrm{~mL}$ min ${ }^{-1}$; time on stream, $20 \mathrm{~h}$. b Catalyst stability. Reaction conditions: $\mathrm{H}_{2} / \mathrm{CO}=1: 1 ; P=5.0 \mathrm{MPa} ; \mathrm{F}=25 \mathrm{~mL} \mathrm{~min}^{-1} ; T=543 \mathrm{~K}$. c Effect of $\mathrm{H}_{2} / \mathrm{CO}$ ratio. Reaction condition: $P=5.0 \mathrm{MPa} ; F=25 \mathrm{~mL} \mathrm{~min}{ }^{-1} ; T=583 \mathrm{~K}$; time on stream, $20 \mathrm{~h}$. d Effect of total pressure. Reaction condition: $\mathrm{H}_{2} / \mathrm{CO}=1: 1 ; F=25 \mathrm{~mL}$ min ${ }^{-1} ; T=$ $583 \mathrm{~K}$; time on stream, $20 \mathrm{~h}$. e Effect of $\mathrm{CO}$ partial pressure at a fixed $\mathrm{H}_{2}$ pressure. Reaction conditions: $P\left(\mathrm{H}_{2}\right)=2.5 \mathrm{MPa} ; T=583 \mathrm{~K} ; F=40 \mathrm{~mL}$ min ${ }^{-1} ; P=$ $5 \mathrm{MPa}$; time on stream, $20 \mathrm{~h}$. $\mathbf{f}$ Effect of $\mathrm{H}_{2}$ partial pressure at a fixed $\mathrm{CO}$ pressure. Reaction conditions: $P(\mathrm{CO})=2.0 \mathrm{MPa} ; T=583 \mathrm{~K} ; F=40 \mathrm{~mL}$ min ${ }^{-1} ; P=$ $5 \mathrm{MPa}$; time on stream, $20 \mathrm{~h} . \mathrm{C}_{2+} \mathrm{HC}: \mathrm{C}_{2+}$ hydrocarbons; EA: ethyl acetate; $\mathrm{AA}$ : acetic acid; $r(\mathrm{CO})$ : the rate of $\mathrm{CO}$ conversion. In all cases, the weights of $\mathrm{K}$ $+-\mathrm{ZnO}-\mathrm{ZrO}_{2}, \mathrm{H}-\mathrm{MOR}-\mathrm{DA}-12 \mathrm{MR}$ and $\mathrm{Pt}-\mathrm{Sn} / \mathrm{SiC}$ catalysts were $0.66,0.66$ and $0.66 \mathrm{~g}$, respectively. The experiments in each case were performed for three times. The error bar represents the relative deviation, which is within $5 \%$. 
Furthermore, the three catalysts in the tandem system were very stable, and no changes in $\mathrm{CO}$ conversion and ethanol selectivity were observed in $100 \mathrm{~h}$ of reaction (Fig. 4b).

We further investigated the temperature effect on catalytic behaviours of each catalyst component in each separated reaction. From Arrhenius plots, the apparent activation energies for methanol synthesis, methanol carbonylation and acetic acid hydrogenation were calculated to be 81,71 and $45 \mathrm{~kJ} \mathrm{~mol}^{-1}$ over the $\mathrm{K}^{+}-\mathrm{ZnO}-\mathrm{ZrO}_{2}, \mathrm{H}-\mathrm{MOR}-\mathrm{DA}-12 \mathrm{MR}$ and $\mathrm{Pt}-\mathrm{Sn} / \mathrm{SiC}$ catalysts, respectively (Supplementary Fig. 13). The rate of methanol synthesis is the lowest among the three steps in a temperature range of 503-583 K. These results suggest that methanol synthesis on the $\mathrm{K}^{+}-\mathrm{ZnO}-\mathrm{ZrO}_{2}$ is the rate-determining step in our tandem catalysis.

The conversion of syngas with different $\mathrm{H}_{2} / \mathrm{CO}$ ratios using the $\mathrm{K}^{+}-\mathrm{ZnO}-\mathrm{ZrO}_{2}|\mathrm{H}-\mathrm{MOR}-\mathrm{DA}-12 \mathrm{MR}| \mathrm{Pt}-\mathrm{Sn} / \mathrm{SiC}$ system showed that upon increasing the $\mathrm{H}_{2} / \mathrm{CO}$ ratio from $0.25: 1$ to $1: 1$, the $\mathrm{CO}$ conversion increased from 3.2 to $5.7 \%$, while the ethanol selectivity decreased only slightly from 75 to $70 \%$ (Fig. 4c). A further increase in the $\mathrm{H}_{2} / \mathrm{CO}$ ratio further increased $\mathrm{CO}$ conversion, but the selectivity of ethanol decreased significantly and those of $\mathrm{C}_{2}-\mathrm{C}_{4}$ olefins, paraffins and $\mathrm{CO}_{2}$ increased at the same time. Similarly, the increase in the $\mathrm{H}_{2} / \mathrm{CO}$ ratio to $>1: 1$ significantly decreased the selectivity of acetic acid and increased those of $\mathrm{C}_{2}-\mathrm{C}_{4}$ olefins and $\mathrm{CO}_{2}$ over the $\mathrm{K}^{+}-\mathrm{ZnO}-\mathrm{ZrO}_{2} \mid \mathrm{H}-\mathrm{MOR}-\mathrm{DA}-12 \mathrm{MR}$ combination (Supplementary Table 8). Thus, a higher $\mathrm{H}_{2} / \mathrm{CO}$ ratio favoured $\mathrm{CO}$ conversion but was unbeneficial to the selectivity of ethanol or acetic acid. Therefore, the present tandem system is applicable to the transformation of syngas with a wide range of $\mathrm{H}_{2} / \mathrm{CO}$ ratios, particularly suitable for that derived from biomass or coal with a $\mathrm{H}_{2} / \mathrm{CO}$ ratio of $0.5: 1-1: 1$.

The total pressure of syngas also significantly affected the catalytic performance (Fig. 4d). Hydrocarbons, in particular $\mathrm{C}_{2}-\mathrm{C}_{4}$ olefins, were the major products at a lower syngas pressure. The increase in syngas pressure from 0.5 to $2.0 \mathrm{MPa}$ not only enhanced $\mathrm{CO}$ conversion but also increased the selectivity of ethanol from 11 to $76 \%$ at the expense of that of hydrocarbons. These results indicate that a lower pressure would retard the carbonylation of $\mathrm{CH}_{3} \mathrm{OH}$ while accelerate the $\mathrm{MTH}$ reaction in zeolite.

The effects of partial pressures of $\mathrm{CO}$ and $\mathrm{H}_{2}$, denoted as $P$ (CO) and $P\left(\mathrm{H}_{2}\right)$, on syngas conversions with $\mathrm{K}^{+}-\mathrm{ZnO}-\mathrm{ZrO}_{2} \mid \mathrm{H}-$ MOR-DA-12MR $\mid \mathrm{Pt}-\mathrm{Sn} / \mathrm{SiC}$ at $583 \mathrm{~K}$ are displayed in Fig. $4 \mathrm{e}$ and $\mathrm{f}$. The rate of $\mathrm{CO}$ conversion, $r(\mathrm{CO})$, depended strongly on both $P(\mathrm{CO})$ and $P\left(\mathrm{H}_{2}\right)$. Further analyses reveal that the experimental data could be fitted to a Langmuir-Hinshelwood kinetic model for the reaction between adsorbed $\mathrm{CO}$ and dissociatively adsorbed $\mathrm{H}$ species (Supplementary Fig. 14 and Supplementary Note 2). This kinetic behaviour is similar to that reported for the conversion of syngas to lower olefins over a $\mathrm{ZnO}-\mathrm{ZrO}_{2} / \mathrm{SSZ}-13$ catalyst, where methanol synthesis on $\mathrm{ZnO}-\mathrm{ZrO}_{2}$ is the rate-determining step ${ }^{30}$. The result here further suggests that the conversion of syngas to methanol is the ratedetermining step in our tandem system. As expected, the product selectivity was also affected by $P(\mathrm{CO})$ and $P\left(\mathrm{H}_{2}\right)$. A higher $P(\mathrm{CO})$ favoured ethanol formation, whereas a higher $P\left(\mathrm{H}_{2}\right)$ was unbeneficial to ethanol selectivity, similar to the trend observed for changing the $\mathrm{H}_{2} / \mathrm{CO}$ ratio.

Interplay between different steps and compatibility. The compatibility is a crucial factor in determining the performance of the tandem catalysis. Although the three catalysts in our tandem system are separated by quartz wool, the interplay between different steps also plays a pivotal role. The carbonylation of methanol with $\mathrm{CO}$ involves $\mathrm{C}-\mathrm{C}$ coupling and is a key step. The ratio of $\mathrm{CO} / \mathrm{CH}_{3} \mathrm{OH}$, which is crucial to methanol carbonylation, is determined by the $\mathrm{CO}$ conversion in methanol synthesis, i.e., the first step. Too higher a CO conversion in the first step would lead to a lower $\mathrm{CO} / \mathrm{CH}_{3} \mathrm{OH}$ ratio and may be detrimental to the carbonylation reaction. We found that the efficiency of methanol carbonylation on H-MOR-DA-12MR depended on the CO/ $\mathrm{CH}_{3} \mathrm{OH}$ ratio and reaction temperature (Supplementary Table 9). To keep a high efficiency of methanol carbonylation, the $\mathrm{CO} /$ $\mathrm{CH}_{3} \mathrm{OH}$ ratio should be controlled at $\geq 300$ at $503 \mathrm{~K}$ or $\geq 8.5$ at $583 \mathrm{~K}$. This means that the $\mathrm{CO}$ conversion in the first step should be controlled at a level of $\sim 0.5 \%$ at $503 \mathrm{~K}$ or at $10.5 \%$ at $583 \mathrm{~K}$ to keep an adequate $\mathrm{CO} / \mathrm{CH}_{3} \mathrm{OH}$ ratio for the second step. This would limit the overall CO conversion at $\leq 21 \%$ at $583 \mathrm{~K}$ by taking into account a further $\mathrm{CO}$ consumption in the subsequent carbonylation.

The incompatibility made $\mathrm{Cu}-\mathrm{Zn}-\mathrm{Al}$ oxide, a well-known methanol-synthesis catalyst, not a good candidate for the first step in the tandem system. At $503 \mathrm{~K}$, a CO conversion of $11 \%$ was obtained with $\mathrm{CH}_{3} \mathrm{OH}$ selectivity of $95 \%$ over $\mathrm{Cu}-\mathrm{Zn}-\mathrm{Al}$ oxide alone, but the $\mathrm{Cu}-\mathrm{Zn}-\mathrm{Al} \mid \mathrm{H}-\mathrm{MOR}-\mathrm{DA}-12 \mathrm{MR}$ combination provided DME as the major product with very low selectivity of acetic acid (Supplementary Table 10). At $583 \mathrm{~K}$, the $\mathrm{CH}_{3} \mathrm{OH}$ selectivity became low (30\%) over the $\mathrm{Cu}-\mathrm{Zn}-\mathrm{Al}$ oxide and the $\mathrm{Cu}-\mathrm{Zn}-\mathrm{Al} \mid \mathrm{H}-\mathrm{MOR}-\mathrm{DA}-12 \mathrm{MR}$ mainly catalysed the formation of hydrocarbons (Supplementary Table 10). The control of CO conversion by decreasing the amount of $\mathrm{Cu}-\mathrm{Zn}-\mathrm{Al}$ component to keep a reasonably high $\mathrm{CO} / \mathrm{CH}_{3} \mathrm{OH}$ ratio for the second step could offer reasonably high selectivity of acetic acid using the $\mathrm{Cu}-\mathrm{Zn}-\mathrm{Al} \mid \mathrm{H}-\mathrm{MOR}-\mathrm{DA}-12 \mathrm{MR}$ combination (Supplementary Table 10). The selectivities of ethanol could reach $81 \%, 71 \%$ and $60 \%$ at CO conversions of $1.5 \%, 3.8 \%$ and $5.5 \%$ at 503,523 and $543 \mathrm{~K}$, respectively, when the $\mathrm{Pt}-\mathrm{Sn} / \mathrm{SiC}$ catalyst was further combined. These performances were inferior to those with the $\mathrm{K}^{+}-\mathrm{ZnO}-\mathrm{ZrO}_{2} \mid$ H-MOR-DA-12MR $\mid \mathrm{Pt}-\mathrm{Sn} / \mathrm{SiC}$ system.

The compatibility of the catalyst with syngas stream, which contains both $\mathrm{CO}$ and $\mathrm{H}_{2}$, is also important for the carbonylation and hydrogenation reactions. For the normal carbonylation reaction, the catalyst works under $\mathrm{CO}$ atmosphere without $\mathrm{H}_{2}{ }^{21,36,41-43}$. Our studies reveal that the presence of $\mathrm{H}_{2}$ did not significantly change the performance of H-MOR-DA-12MR in the carbonylation of methanol (Supplementary Table 11). The catalyst underwent gradual deactivation in $\mathrm{CH}_{3} \mathrm{OH}$ carbonylation with $\mathrm{CO}$ in the absence of $\mathrm{H}_{2}$ (Fig. 5a). The deactivation of $\mathrm{H}$ MOR in carbonylation is believed to arise from coke deposition in 12-MR channels ${ }^{55}$. The presence of $\mathrm{H}_{2}$ significantly inhibited catalyst deactivation probably by suppressing the coke deposition (Supplementary Fig. 15). No changes in methanol conversion and acetic acid selectivity were observed in $50 \mathrm{~h}$ of reaction (Fig. 5a). We believe that this results in the superior stability of the present tandem catalytic system. Thus, the syngas stream not only offers $\mathrm{CO}$ for carbonylation but also ensures high stability owing to the presence of $\mathrm{H}_{2}$.

We found that the co-existence of $\mathrm{CO}$ affected the hydrogenation of acetic acid on supported Pt catalyst. The conversion of acetic acid and the selectivity of ethanol on the $\mathrm{Pt} / \mathrm{SiC}$ were both lower than those on the $\mathrm{Pt}-\mathrm{Sn} / \mathrm{SiC}$ during the hydrogenation of acetic acid with $\mathrm{H}_{2}$ alone. The use of syngas instead of $\mathrm{H}_{2}$ further decreased the conversion of acetic acid and the selectivity of ethanol on the $\mathrm{Pt} / \mathrm{SiC}$ catalyst (Fig. $5 \mathrm{~b}$ ). On the other hand, neither the acetic acid conversion nor the ethanol selectivity changed significantly in the presence of $\mathrm{CO}$ over the $\mathrm{Pt}-\mathrm{Sn} / \mathrm{SiC}$ catalyst. Thus, the presence of Sn not only improves the activity and selectivity for acetic acid hydrogenation but also eliminates the negative effect of $\mathrm{CO}$. As already mentioned, the presence of $\mathrm{Sn}$ markedly suppresses $\mathrm{CO}$ chemisorption on $\mathrm{Pt}$ surfaces 

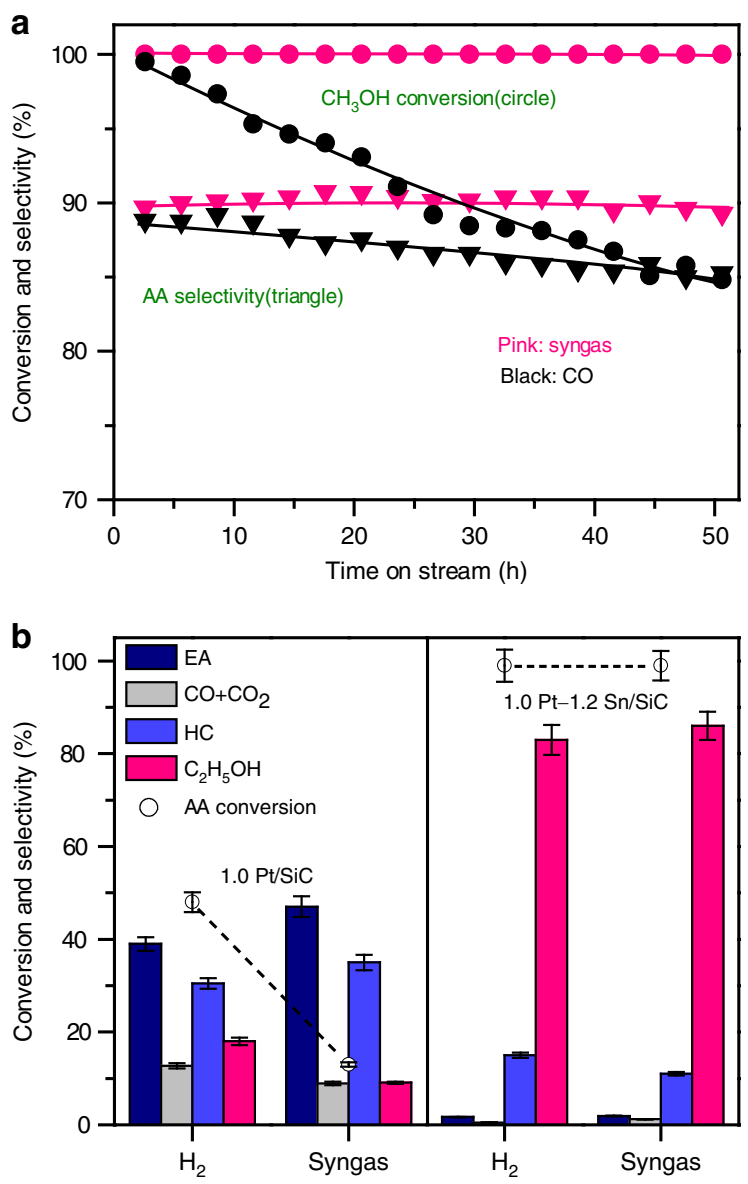

Fig. 5 Catalyst compatibility in syngas stream. a Catalytic performances of $\mathrm{H}-\mathrm{MOR}-\mathrm{DA}-12 \mathrm{MR}$ for methanol carbonylation in $\mathrm{CO}$ and syngas streams. AA: acetic acid. Reaction conditions: H-MOR-DA-12MR, $1.0 \mathrm{~g}$; $P=5.0 \mathrm{MPa} ; T=583 \mathrm{~K} ; \mathrm{F}\left(\mathrm{CH}_{3} \mathrm{OH}\right)=1.48 \mathrm{mmol} \mathrm{h}^{-1} ; \mathrm{F}(95 \% \mathrm{CO}-5 \% \mathrm{Ar})$ or $\mathrm{F}\left(48 \% \mathrm{CO}-48 \% \mathrm{H}_{2}-4 \% \mathrm{Ar}\right)=12$ or $24 \mathrm{~mL} \mathrm{~min}^{-1}$. b Catalytic performances of $\mathrm{Pt} / \mathrm{SiC}$ and $\mathrm{Pt}-\mathrm{Sn} / \mathrm{SiC}$ for acetic acid hydrogenation in $\mathrm{H}_{2}$ and syngas streams. EA: ethyl acetate; HC: hydrocarbons; AA: acetic acid. Reaction conditions: $\mathrm{Pt} / \mathrm{SiC}$ or Pt-Sn/SiC, $0.66 \mathrm{~g} ; \mathrm{P}=5.0 \mathrm{MPa} ; T=583 \mathrm{~K} ; F(\mathrm{AA})=$ $1.05 \mathrm{mmol} \mathrm{h}^{-1} ; \mathrm{F}\left(\mathrm{H}_{2}\right)$ or $\mathrm{F}\left(48 \% \mathrm{CO}-48 \% \mathrm{H}_{2}-4 \% \mathrm{Ar}\right)=12$ or $25 \mathrm{~mL} \mathrm{~min}^{-1}$; time on stream, $20 \mathrm{~h}$. The experiments in each case were performed for three times. The error bar represents the relative deviation, which is within 5\%.

(Supplementary Fig. 10c), thus enabling the hydrogenation of acetic acid to proceed efficiently and selectively to ethanol.

The proximity between catalytically functional components could significantly affect catalytic behaviours in tandem catalysis $^{27,28,30,31,56-58}$. We found that the change in the size of granules of each catalyst component in a range of $125-850 \mu \mathrm{m}$ with the layer-by-layer $\left(\mathrm{K}^{+}-\mathrm{ZnO}-\mathrm{ZrO}_{2}|\mathrm{H}-\mathrm{MOR}-\mathrm{DA}-12 \mathrm{MR}|\right.$ $\mathrm{Pt}-\mathrm{Sn} / \mathrm{SiC}$ ) configuration did not change the catalytic performance significantly (Supplementary Table 12). The decrease in the amount of quartz wool or the height of quartz-wool bed to separate the catalyst layers also did not change catalytic performances until the amount of quartz wool decreased to $\leq$ $0.015 \mathrm{~g}$, which could not completely separate the catalyst layers and thus led to direct contact of catalyst components to some extent (Supplementary Table 13). The selectivity of ethanol decreased and that of lower olefins, in particular ethylene, increased as the amount of quartz wool decreased to $\leq 0.015 \mathrm{~g}$. The $\mathrm{CO}_{2}$ selectivity increased at the same time. This suggests that ethanol formed on $\mathrm{Pt}-\mathrm{Sn} / \mathrm{SiC}$ may undergo dehydration to ethylene on zeolite, which has direct contact with the $\mathrm{Pt}-\mathrm{Sn} / \mathrm{SiC}$ due to the too smaller amount of quartz wool. We confirmed that ethanol could be easily converted to ethylene over $\mathrm{H}$ MOR-DA-12MR under our reaction conditions (Supplementary Table 14). The formation of ethylene at the expense of ethanol has also been observed in the conversion of acetic acid upon increasing the proximity between the two components in $\mathrm{H}$ MOR-DA-12MR $\mid \mathrm{Pt}-\mathrm{Sn} / \mathrm{SiC}$ (Supplementary Table 15). We further measured catalytic behaviours of mixed catalysts composed of three components. The use of mixed granules of three catalysts (i.e., $\mathrm{K}^{+}-\mathrm{ZnO}-\mathrm{ZrO}_{2}, \mathrm{H}-\mathrm{MOR}-\mathrm{DA}-12 \mathrm{MR}$ and $\mathrm{Pt}-\mathrm{Sn}$ / $\mathrm{SiC}$ ) with sizes of $250-600 \mu \mathrm{m}$ instead of the layer-by-layer configuration led to the disappearance of ethanol (Supplementary Table 16). $\mathrm{C}_{2}-\mathrm{C}_{4}$ olefins (mainly ethylene) became the major products; the selectivities of $\mathrm{C}_{2}-\mathrm{C}_{4}$ olefins and ethylene reached $80 \%$ and $55 \%$, respectively. A further increase in the proximity by grinding fine powders of the three components significantly increased ethylene selectivity to $68 \%$, although the $\mathrm{C}_{2}-\mathrm{C}_{4}$ olefin selectivity only increased slightly. The $\mathrm{CO}_{2}$ selectivity also became higher by using the mixed catalysts. The excess amount of $\mathrm{CO}_{2}$ possibly arises from the WGS reaction on metal oxide surfaces of the mixed catalyst. The conversion of acetic acid also led to the formation of lower olefins instead of ethanol over the mixed catalyst composed of $\mathrm{Pt}-\mathrm{Sn} / \mathrm{SiC}$ and $\mathrm{H}-\mathrm{MOR}-\mathrm{DA}-12 \mathrm{MR}$ in close contact (Supplementary Table 17). These results demonstrate that the complete separation of the three catalyst components is a key to the selective formation of ethanol.

As compared with the routes via DME and methyl acetate, by which the highest ethanol selectivity obtained is $\sim 50 \%{ }^{31-35}$, we have achieved significantly higher ethanol selectivity (70-90\%) from syngas through a single-pass route via methanol and acetic acid intermediates. Furthermore, although ethanol can be produced through three separated processes, i.e., methanol/ DME synthesis, methanol/DME carbonylation and acetic acid/ methyl acetate hydrogenation (Fig. 1, Routes B and C), the singlepass route reported in this work would simplify the reaction and separation/purification processes as well as the required equipment, and can thus reduce the cost and improve the operation efficiency. The tandem catalysis in one reactor can also bring about beneficial effect on the stability of zeolite catalyst for carbonylation reaction, which is known as a challenging issue ${ }^{55}$. For future studies, to further increase the activity by catalyst modification or reactor engineering is required. For example, to design a reactor with three catalyst layers controlled at different temperatures may overcome the $\mathrm{CO}$ conversion limitation. The separation of $\mathrm{H}_{2} \mathrm{O}$ formed together with ethanol in the last step needs consideration to obtain anhydrous ethanol. The extractive distillation, a technique widely used for the separation of ethanol-water azeotropes derived from ethylene hydration and sugar fermentation ${ }^{59}$, as well as membranes ${ }^{60,61}$ may fulfil this task. An anti-corrosive reactor may also be necessary if the concentration of acetic acid intermediate becomes considerable in the large-scale process.

\section{Discussion}

We have succeeded in designing a triple tandem catalytic system that can accomplish selective conversion of syngas into ethanol. The system is composed of potassium-modified $\mathrm{ZnO}-\mathrm{ZrO}_{2}$, zeolite $\mathrm{H}-\mathrm{MOR}-\mathrm{DA}-12 \mathrm{MR}$ and $\mathrm{Pt}-\mathrm{Sn} / \mathrm{SiC}$ in one reactor, which catalyse syngas to methanol, methanol carbonylation to acetic acid and hydrogenation of acetic acid to ethanol in tandem. The ethanol selectivity reaches $90 \%$ and $81 \%$ at CO conversions of $0.7 \%$ and $4.0 \%$ at 503 and $543 \mathrm{~K}$, respectively. At a CO conversion of $\sim 10 \%$, the ethanol selectivity could be sustained at $64 \%$. The system is very stable and no deactivation is observed in $100 \mathrm{~h}$. We 
have demonstrated that to keep the high selectivity of each step by carefully designing the corresponding catalyst is the key to obtaining high ethanol selectivity. The interplay between different steps and the compatibility of catalysts in syngas stream are also crucial. Methanol synthesis is the rate-determining step and to keep a sufficiently high $\mathrm{CO} / \mathrm{CH}_{3} \mathrm{OH}$ ratio is important for methanol carbonylation, which determines $\mathrm{C}-\mathrm{C}$ coupling. The presence of $\mathrm{H}_{2}$ improves the stability of zeolite for methanol carbonylation, whereas the co-existence of $\mathrm{CO}$ requires careful design of catalysts for acetic acid hydrogenation to avoid the poisoning effect of $\mathrm{CO}$. The present work not only presents a promising catalytic system for high-selective conversion of syngas into ethanol but also offers a method of controlling reaction selectivity by decoupling a complicated and uncontrollable reaction into well-controlled tandem reactions.

\section{Methods}

Synthesis of metal oxide catalysts. The $\mathrm{ZnO}-\mathrm{ZrO}_{2}$ and $\mathrm{K}^{+}-\mathrm{ZnO}-\mathrm{ZrO}_{2}$ were synthesized by a sol-gel method ${ }^{30}$. Typically, $\mathrm{Zn}\left(\mathrm{NO}_{3}\right)_{2} \cdot 6 \mathrm{H}_{2} \mathrm{O}, \mathrm{Zr}\left(\mathrm{NO}_{3}\right)_{4} \cdot 5 \mathrm{H}_{2} \mathrm{O}$ and citric acid were dissolved in $150 \mathrm{~mL}$ deionized water. $\mathrm{KNO}_{3}$ was also added in the solution for the synthesis of $\mathrm{K}^{+}-\mathrm{ZnO}-\mathrm{ZrO}_{2}$. The mixture was evaporated at $363 \mathrm{~K}$ until a viscous gel was obtained. Then, the resultant was heated to $473 \mathrm{~K}$ for $5 \mathrm{~h}$ and calcined at $773 \mathrm{~K}$ in air for $5 \mathrm{~h}$. The typical molar ratios of $\mathrm{Zn} / \mathrm{Zr}$ for the $\mathrm{ZnO}-\mathrm{ZrO}_{2}$ and $\mathrm{K} / \mathrm{Zn} / \mathrm{Zr}$ for the $\mathrm{K}^{+}-\mathrm{ZnO}-\mathrm{ZrO}_{2}$ were $1: 8$ and $0.07: 1: 8$, respectively, unless otherwise specified. The $\mathrm{ZnAl}_{2} \mathrm{O}_{4}{ }^{31}, \mathrm{ZnGa}_{2} \mathrm{O}_{4}{ }^{62}$ and $\mathrm{ZnCr}_{2} \mathrm{O}_{4}{ }^{63}$ compounds were synthesized by a co-precipitation method. As an example, for the synthesis of $\mathrm{ZnAl}_{2} \mathrm{O}_{4}, \mathrm{Zn}\left(\mathrm{NO}_{3}\right)_{2} \cdot 6 \mathrm{H}_{2} \mathrm{O}(2.97 \mathrm{~g})$ and $\mathrm{Al}\left(\mathrm{NO}_{3}\right)_{3} \cdot 9 \mathrm{H}_{2} \mathrm{O}(7.56 \mathrm{~g})$ were dissolved in $100 \mathrm{~mL}$ deionized water. Then, an aqueous ammonia solution ( $25 \mathrm{wt} \%)$ was added dropwise into the mixed solution at room temperature until the $\mathrm{pH}$ reached 7 . The obtained precipitate was aged for $2 \mathrm{~h}$ at $343 \mathrm{~K}$. Then, the solid product was recovered by filtration, washing with deionized water and drying overnight at 373 $\mathrm{K}$. The $\mathrm{ZnAl}_{2} \mathrm{O}_{4}$ compound was obtained after calcination in air at $773 \mathrm{~K}$ for $5 \mathrm{~h}$. $\mathrm{Ga}\left(\mathrm{NO}_{3}\right)_{3} \cdot 6 \mathrm{H}_{2} \mathrm{O}$ and $\mathrm{Cr}\left(\mathrm{NO}_{3}\right)_{3} \cdot 9 \mathrm{H}_{2} \mathrm{O}$ were employed instead of $\mathrm{Al}\left(\mathrm{NO}_{3}\right)_{3} \cdot 9 \mathrm{H}_{2} \mathrm{O}$ for the synthesis of $\mathrm{ZnGa}_{2} \mathrm{O}_{4}{ }^{62}$ and $\mathrm{ZnCr}_{2} \mathrm{O}_{4}{ }^{63}$. $\left(\mathrm{NH}_{4}\right)_{2} \mathrm{CO}_{3}$ aqueous solution was used as the precipitant in the case of $\mathrm{ZnCr}_{2} \mathrm{O}_{4}$ synthesis ${ }^{63}$. The $\mathrm{ZrO}_{2}-\mathrm{In}_{2} \mathrm{O}_{3}$ composite with a $\mathrm{Zr} / \mathrm{In}$ molar ratio of $1: 2$ was prepared by a similar coprecipitation method using $\mathrm{Zr}\left(\mathrm{NO}_{3}\right)_{4} \cdot 5 \mathrm{H}_{2} \mathrm{O}$ and $\mathrm{In}\left(\mathrm{NO}_{3}\right)_{3} \cdot 4.5 \mathrm{H}_{2} \mathrm{O}$ as starting materials ${ }^{38}$. The $\mathrm{Cu}-\mathrm{Zn}-\mathrm{Al}$ oxide was synthesized by a co-precipitation method. Typically, $\mathrm{Cu}\left(\mathrm{NO}_{3}\right)_{2} \cdot 3 \mathrm{H}_{2} \mathrm{O}(7.25 \mathrm{~g}), \mathrm{Zn}\left(\mathrm{NO}_{3}\right)_{2} \cdot 6 \mathrm{H}_{2} \mathrm{O}(4.46 \mathrm{~g})$ and $\mathrm{Al}\left(\mathrm{NO}_{3}\right)_{3} \cdot 9 \mathrm{H}_{2} \mathrm{O}$ $(1.88 \mathrm{~g})$ were dissolved in $50 \mathrm{~mL}$ deionized water. Then, the mixed aqueous solution and an aqueous solution of $\mathrm{Na}_{2} \mathrm{CO}_{3}\left(1.0 \mathrm{~mol} \mathrm{~mL}^{-1}\right)$ as a precipitant were simultaneously added to a glass beaker with $100 \mathrm{~mL}$ deionized water under vigorous stirring at $343 \mathrm{~K}$. The $\mathrm{pH}$ value of the aqueous solution was kept at 7.0. The obtained precipitate was aged for $1 \mathrm{~h}$. Then, the solid product was recovered by filtration, followed by washing thoroughly with deionized water. The product was dried overnight at $373 \mathrm{~K}$, followed by calcination in air at $623 \mathrm{~K}$ for $5 \mathrm{~h}$ and reduction in $\mathrm{H}_{2}$ flow at $523 \mathrm{~K}$ for $2 \mathrm{~h}$.

Zeolites and selective dealumination of H-MOR. Zeolites used in this work, including SAPO-34, H-beta, H-ZSM-5, H-ZSM-35 and H-MOR, were purchased from Nankai University Catalyst Co. Selective dealumination of H-MOR with a Si/ $\mathrm{Al}$ ratio of 13 was performed by a high-temperature steam-treatment method ${ }^{31,43}$. In brief, H-MOR (30-60 mesh, 3.3 g) was first pretreated by pyridine in a stream containing pyridine in $\mathrm{N}_{2}$ (pyridine pressure of $2 \mathrm{kPa}$ in $\mathrm{N}_{2}$ gas flow with a flow rate of $70 \mathrm{~mL} \mathrm{~min}^{-1}$ ) for $1 \mathrm{~h}$ in a quartz-tube reactor. A Py-MOR sample, whose $12-\mathrm{MR}$ channel was occupied by pyridine molecules, was obtained. Then, the PyMOR sample was treated in a $0.05 \mathrm{M}$ aqueous $\mathrm{NaNO}_{3}$ solution at $353 \mathrm{~K}$ for $2 \mathrm{~h}$ to allow the protons in the 8-MR channels being exchanged by $\mathrm{Na}^{+}$cations to obtain an $\mathrm{H}-\mathrm{MOR}-\mathrm{Py}-\mathrm{Na}-8 \mathrm{MR}$. The resulting solid was subsequently calcined at $873 \mathrm{~K}$ in air for $5 \mathrm{~h}$ to remove pyridine molecules in the $12-\mathrm{MR}$ channels to obtain an $\mathrm{H}$ MOR-Na-8MR sample. The steam treatment of the H-MOR-Na-8MR was conducted at $723 \mathrm{~K}$ for $5 \mathrm{~h}$ in the quartz reactor with a stream containing $26 \% \mathrm{H}_{2} \mathrm{O}$ in $\mathrm{N}_{2}$. The dealumination was expected to occur selectively for the Al sites in the 12MR channels ${ }^{43}$. The obtained H-MOR-Na-8MR-steam sample was ion-

exchanged by using $\mathrm{NH}_{4} \mathrm{Cl}$ aqueous solution $(1.0 \mathrm{M})$ for three times at $353 \mathrm{~K}$ for 2 h. The solid $\mathrm{NH}_{4}$-MOR sample was recovered by filtration and washing with deionized water, and finally calcined at $773 \mathrm{~K}$ in air for $5 \mathrm{~h}$. The sample thus obtained was denoted as H-MOR-DA-12MR.

Synthesis of supported metal catalysts. Supported Pt and Pt-Sn catalysts were prepared by a chemical reduction method. SiC ( $\beta$-phase, nanopowder) with a purity of $95 \%$ was purchased from Alfa Aesar. For the preparation of the $\mathrm{Pt}-\mathrm{Sn} / \mathrm{SiC}$ catalyst, $\mathrm{SiC}(1.0 \mathrm{~g})$ was first dispersed in ethylene glycol $(20 \mathrm{~mL})$ and sonicated for $0.5 \mathrm{~h}$. Aqueous solutions of $\mathrm{H}_{2} \mathrm{PtCl}_{6}\left(3.7 \mathrm{mg} \mathrm{mL}^{-1}\right)$ and $\mathrm{SnCl}_{2}\left(4.0 \mathrm{mg} \mathrm{mL}^{-1}\right)$ were added to above solution. Then, a sodium dodecyl sulphate (SDS) solution $(0.6 \mathrm{mg}$ $\mathrm{mL}^{-1}$ ) was added into the mixed solution and stirred for $1 \mathrm{~h}$. Subsequently, $\mathrm{NaBH}_{4}$ aqueous solution was added dropwise to the mixed solution and stirred at room temperature for $3 \mathrm{~h}$. The solid product was recovered by filtration, washing and drying at $393 \mathrm{~K}$ overnight. The powdery Pt-Sn/SiC catalyst was calcined at $623 \mathrm{~K}$ for $4 \mathrm{~h}$. The typical loadings of $\mathrm{Pt}$ and $\mathrm{Sn}$ were $1.0 \mathrm{wt} \%$ and $1.2 \mathrm{wt} \%$, respectively. The same procedure was used for the preparation of the $\mathrm{Pt} / \mathrm{SiC}$ catalyst without addition of $\mathrm{SnCl}_{2} \cdot 5 \mathrm{H}_{2} \mathrm{O}$. The $\mathrm{Pd} / \mathrm{SiC}$ and $\mathrm{Rh} / \mathrm{SiC}$ were also prepared using the same procedure using $\mathrm{PdCl}_{2}$ and $\mathrm{RhCl}_{3}$ aqueous solutions instead of $\mathrm{H}_{2} \mathrm{PtCl}_{6}$ aqueous solution. The $\mathrm{Cu} / \mathrm{SiO}_{2}$ catalyst with a $\mathrm{Cu}$ loading amount of $20 \mathrm{wt} \%$ was prepared by an impregnation method using $\mathrm{SiO}_{2}$ (fused silica) and $\mathrm{Cu}\left(\mathrm{NO}_{3}\right)_{2}$ aqueous solution as the starting materials. After the impregnation, the sample was dried in vacuum at $323 \mathrm{~K}$, followed by calcination in air at $673 \mathrm{~K}$ for $4 \mathrm{~h}$ and reduction in $\mathrm{H}_{2}$ flow at $523 \mathrm{~K}$ for $2 \mathrm{~h}$.

Catalytic reaction. The conversion of syngas was performed on a high-pressure fixed-bed flow reactor (titanium reactor with an inner diameter of $10 \mathrm{~mm}$ ) designed by Xiamen Han De Engineering Co., Ltd. The catalysts, which possessed grain sizes of 250-600 $\mu \mathrm{m}$ (30-60 mesh), were used for each reaction. In the titanium reactor, the catalysts with different functions were separated by quartz wool. For example, the catalyst bed containing three layers of catalysts of $\mathrm{K}$ $+-\mathrm{ZnO}-\mathrm{ZrO}_{2}, \mathrm{H}-\mathrm{MOR}-\mathrm{DA}-12 \mathrm{MR}$ and $\mathrm{Pt}-\mathrm{Sn} / \mathrm{SiC}$ separated by quartz wool was denoted as $\mathrm{K}^{+}-\mathrm{ZnO}-\mathrm{ZrO}_{2}|\mathrm{H}-\mathrm{MOR}-\mathrm{DA}-12 \mathrm{MR}| \mathrm{Pt}-\mathrm{Sn} / \mathrm{SiC}$. Syngas containing argon with a concentration of $4 \%$, which was used as an internal standard for the calculation of $\mathrm{CO}$ conversion, was introduced into the reactor. The flow rate of syngas was typically manipulated at $25 \mathrm{~mL} \mathrm{~min}^{-1}$ (STP) unless otherwise stated. The pressure of syngas was typically 5.0 MPa. The conversion of $\mathrm{CH}_{3} \mathrm{OH}$ in $\mathrm{CO}$ or syngas stream was performed in the same reactor. Liquid methanol with a flow rate of $1.48 \mathrm{mmol} \mathrm{h}^{-1}$ was fed into the reactor by a Series III Pump with $95 \% \mathrm{CO}-5 \% \mathrm{Ar}$ or syngas $\left(48 \% \mathrm{H}_{2}-48 \% \mathrm{CO}-4 \% \mathrm{Ar}\right)$ flow. The conversion of $\mathrm{CH}_{3} \mathrm{COOH}$ in $\mathrm{H}_{2}$ or syngas stream was performed by feeding liquid acetic acid with a flow rate of 1.05 mmol h $\mathrm{h}^{-1}$ into the reactor by a Series III Pump with pure $\mathrm{H}_{2}$ or syngas $(48 \%$ $\mathrm{H}-48 \% \mathrm{CO}-4 \%$ Ar) flow. The conversion of $\mathrm{CH}_{3} \mathrm{CH}_{2} \mathrm{OH}$ in $\mathrm{N}_{2}$ stream was performed by feeding liquid ethanol with a flow rate of $1.05 \mathrm{mmol} \mathrm{h}^{-1}$ into the reactor by a Series III Pump with pure $\mathrm{N}_{2}$ flow. Products were analysed by an online gas chromatograph (Ruimin GC2060, Shanghai), which was equipped with a thermal conductivity detector (TCD) and a flame ionization detector (FID). A TDX-01 packed column was connected to the TCD for the separation and analyses of Ar, $\mathrm{CO}, \mathrm{CH}_{4}$ and $\mathrm{CO}_{2}$. A RT-Q-BOND-PLOT capillary column was connected to the FID for the separation and analyses of organic oxygenated compounds (including methanol, DME, ethanol, methyl acetate, acetic acid and ethyl acetate) and $\mathrm{C}_{1}-\mathrm{C}_{10}$ hydrocarbons. The product selectivity was calculated on a molar carbon basis. The selectivity of $\mathrm{CO}_{2}$, which was formed by the WGS reaction, was calculated separately from CO hydrogenation products. Carbon balances were all about $95-99 \%$. Each catalytic reaction was typically performed for three times and the relative deviation was within $5 \%$, confirming that the catalytic performance is reproducible.

Catalyst characterization. X-ray diffraction (XRD) patterns were recorded on a Rigaku Ultima IV diffractometer (Rigaku, Japan). Cu Ka radiation (40 kV and 30 $\mathrm{mA}$ ) was used as the X-ray source. X-ray fluorescence (XRF) spectroscopy was used to measure the elemental compositions of catalysts in this work. The XRF measurements were performed with a Panalytical Axois Petro XRF instrument with rhodium target $(50 \mathrm{kV}, 50 \mathrm{~mA})$. Transmission electron microscopy (TEM) and line-scan energy-dispersive X-ray spectroscopy (EDS) measurements were performed on a Phillips Analytical FEI Tecnai 20 electron microscope operated at an acceleration voltage of $200 \mathrm{kV}$. The sample was dispersed ultrasonically in ethanol for $5 \mathrm{~min}$, and a drop of solution was deposited onto a carbon-coated copper grid. $\mathrm{X}$-ray photoelectron spectroscopy (XPS) measurements were carried out in an UHV chamber equipped with an Omicron XPS (base pressure $5 \times 10^{-10}$ torr). A monochromatized Al $\mathrm{K}_{\alpha} \mathrm{X}$-ray source and a Sphere 2 analyser were used. After pretreated in $\mathrm{N}_{2}$ at $673 \mathrm{~K}$ or syngas with $\mathrm{H}_{2} / \mathrm{CO}=1$ at $583 \mathrm{~K}$ for $1 \mathrm{~h}$ in a pretreatment chamber directly connected to the detecting chamber, the sample was transferred into the UHV detecting chamber for XPS measurements. The electron paramagnetic resonance (EPR) spectroscopy measurements were carried out on Bruker EMX-10/12 instrument at temperature of $77 \mathrm{~K}$, microwave frequency of $9.43 \mathrm{GHz}$ and microwave power of $19.83 \mathrm{~mW}$. 1,1-Diphenyl-2-picryl-hydrazyl was used as an internal standard to quantify the intensity of EPR signals. $\mathrm{NH}_{3}$ temperature-programmed desorption $\left(\mathrm{NH}_{3}\right.$-TPD) measurements were performed on a Micromeritics Auto Chem II 2920 instrument. Typically, the sample was pretreated in a quartz reactor with a high-purity $\mathrm{He}$ gas flow at $673 \mathrm{~K}$ for $1 \mathrm{~h}$. The adsorption of $\mathrm{NH}_{3}$ was performed at $373 \mathrm{~K}$ in an $\mathrm{NH}_{3}$ - He mixture $\left(10\right.$ vol\% $\mathrm{NH}_{3}$ ) for $1 \mathrm{~h}$, and TPD was performed in He flow by raising the temperature to $1173 \mathrm{~K}$ at a rate of $10 \mathrm{~K} \mathrm{~min}^{-1}$. Fourier-transform infrared (FT-IR) studies were performed with a Nicolet 6700 instrument equipped with an MCT detector. The sample was pressed into a self-supported wafer and placed in an in situ IR cell. After pretreatment under vacuum at $673 \mathrm{~K}$ for $4 \mathrm{~h}$, the sample was cooled to room temperature. Then, FT-IR spectra were recorded from 4000 to $600 \mathrm{~cm}^{-1}$ by averaging 64 scans collected at $4 \mathrm{~cm}^{-1}$ resolution. Pyridine-adsorbed FT-IR measurements were performed with the same instrument. After pretreatment under vacuum at $673 \mathrm{~K}$ for $30 \mathrm{~min}$, the sample was cooled down to $423 \mathrm{~K}$. Then, pyridine adsorption was carried out at $423 \mathrm{~K}$ for $30 \mathrm{~min}$. IR spectra were collected after gaseous or weakly adsorbed pyridine molecules were removed by evacuation at $423 \mathrm{~K}$. The 
amounts of $\mathrm{CO}$ chemisorption were measured at $308 \mathrm{~K}$ on a Micromeritics ASAP $2020 \mathrm{C}$ apparatus. ${ }^{1} \mathrm{H},{ }^{23} \mathrm{Na}$ and ${ }^{27} \mathrm{Al}$ magic angle spinning nuclear magnetic resonance (MAS NMR) experiments were conducted on a Bruker Avance III 400 NMR spectrometer equipped with an $89 \mathrm{~mm}$ wide-bore $9.4 \mathrm{~T}$ superconducting magnet using $4.0 \mathrm{~mm}$ MAS probe tuned to ${ }^{1} \mathrm{H}$ at $400.0 \mathrm{MHz},{ }^{23} \mathrm{Na}$ at $105.8 \mathrm{MHz}$ and ${ }^{27} \mathrm{Al}$ at $104.3 \mathrm{MHz}$, respectively. The reported ${ }^{1} \mathrm{H},{ }^{23} \mathrm{Na}$ and ${ }^{27} \mathrm{Al}$ chemical shifts were referenced to adamantane, $1.0 \mathrm{M} \mathrm{NaCl}$ and $1.0 \mathrm{M} \mathrm{Al}\left(\mathrm{NO}_{3}\right)_{3}$ aqueous solution at 1.91, 0 and $0 \mathrm{ppm}$, respectively. All the samples for NMR measurements were kept under $10^{-3} \mathrm{~Pa}$ for $3 \mathrm{~h}$ at $673 \mathrm{~K}$, before they were cooled down to room temperature. After that, the samples were packed into $4.0 \mathrm{~mm} \mathrm{ZrO}_{2}$ rotors in a $\mathrm{N}_{2}$ glove box. The description of conditions for MAS NMR: (For ${ }^{1} \mathrm{H}$ ) A single $\pi / 2$ pulse $(3.5 \mu \mathrm{s})$ was used for excitation; recycle delay $=1 \mathrm{~s}$; spinning speed $=14.0$ $\mathrm{kHz}$. (For ${ }^{23} \mathrm{Na}$ ) A single pulse corresponding to a $\pi / 4$ flip angle $(1.7 \mu \mathrm{s})$ was used for excitation; recycle delay $=0.1 \mathrm{~s}$; spinning speed $=14.0 \mathrm{kHz}$. $\left(\right.$ For $\left.{ }^{27} \mathrm{Al}\right) \mathrm{A}$ single pulse corresponding to a $\pi / 6$ flip angle $(1.0 \mu \mathrm{s})$ was used for excitation; recycle delay $=0.1 \mathrm{~s}$; spinning speed $=14.0 \mathrm{kHz}$. GC-MS analyses were performed using a Thermo ISQ7000 instrument with a TS- $1 \mathrm{~ms}$ capillary column. $0.05 \mathrm{~g}$ spent zeolite catalysts were dissolved in $0.05 \mathrm{~mL}$ HF solution (20\%). After being neutralized with $5 \mathrm{wt} \% \mathrm{NaOH}$ solution, the soluble cokes were extracted with $0.5 \mathrm{~mL} \mathrm{CH}_{2} \mathrm{Cl}_{2}$ containing $20 \mathrm{ppm} \mathrm{C}_{2} \mathrm{Cl}_{6}$ (internal standard). Thermogravimetric (TG) analysis was performed in air flow on a SDT-Q600 apparatus. The sample was dried at 373 $\mathrm{K}$ for $2 \mathrm{~h}$, then heated to $1073 \mathrm{~K}$ at a rate of $10 \mathrm{~K} \mathrm{~min}^{-1}$ under air flow.

\section{Data availability}

The data supporting the findings of this study are available from the corresponding authors on reasonable request.

Received: 15 April 2019; Accepted: 27 January 2020; Published online: 11 February 2020

\section{References}

1. Cheng, K. et al. Advances in catalysis for syngas conversion to hydrocarbons. Adv. Catal. 60, 125-208 (2017)

2. Zhou, W. et al. New horizon in $\mathrm{C} 1$ chemistry: breaking the selectivity limitation in transformation of syngas and hydrogenation of $\mathrm{CO}_{2}$ into hydrocarbon chemicals and fuels. Chem. Soc. Rev. 48, 3193-3228 (2019).

3. Li, J. et al. Integrated tuneable synthesis of liquid fuels via Fischer-Tropsch technology. Nat. Catal. 1, 787-793 (2018).

4. Farrell, A. E. et al. Ethanol can contribute to energy and environmental goals. Science 311, 506-508 (2006).

5. Spivey, J. J. \& Egbebi, A. Heterogeneous catalytic synthesis of ethanol from biomass-derived syngas. Chem. Soc. Rev. 36, 1514-1528 (2007).

6. Kennes, D., Abubackar, H. N., Diaz, M. C., Veiga, M. \& Kennes, C. Bioethanol production from biomass: carbohydrate vs syngas fermentation. J. Chem. Technol. Biotechnol. 91, 304-317 (2016).

7. Shen, F. \& Liu, R. Research on solid-state ethanol fermentation using dry sweet sorghum stalk particles with active dry yeast. Energy Fuels 23, 519-525 (2009).

8. Luk, H. T., Mondelli, C., Ferré, D. C., Stewart, J. A. \& Pérez-Ramírez, J. Status and prospects in higher alcohols synthesis from syngas. Chem. Soc. Rev. 46, 1358-1426 (2017).

9. Gupta, M., Smith, M. L. \& Spivey, J. J. Heterogeneous catalytic conversion of dry syngas to ethanol and higher alcohols on Cu-based catalysts. ACS Catal. 1, 641-656 (2011).

10. An, Y. et al. Advances in direct production of value-added chemicals via syngas conversion. Sci. China Chem. 60, 887-903 (2017).

11. Ao, M., Pham, G. H., Sunarso, J., Tade, M. O. \& Liu, S. Active centers of catalysts for higher alcohol synthesis from syngas: a review. ACS Catal. 8 , 7025-7050 (2018).

12. Pan, X. et al. Enhanced ethanol production inside carbon-nanotube reactors containing catalytic particles. Nat. Mater. 6, 507-511 (2007).

13. Wang, J., Chernavskii, P. A., Khodakov, A. Y. \& Wang, Y. Structure and catalytic performance of alumina-supported copper-cobalt catalysts for carbon monoxide hydrogenation. J. Catal. 286, 51-61 (2012).

14. Prieto, G. et al. Design and synthesis of copper-cobalt catalysts for the selective conversion of synthesis gas to ethanol and higher alcohols. Angew. Chem. Int. Ed. 53, 6397-6401 (2014).

15. Xiang, Y., Barbosa, R. \& Kruse, N. Higher alcohols through CO hydrogenation over CoCu catalysts: influence of precursor activation. ACS Catal. 4, 2792-2800 (2014).

16. Xiang, Y. \& Kruse, N. Tuning the catalytic CO hydrogenation to straight- and long-chain aldehydes/alcohols and olefins/paraffins. Nat. Commun. 7, 13058 (2016).

17. Lu, Y. et al. Elucidating the copper-Hägg iron carbide synergistic interactions for selective CO hydrogenation to higher alcohols. ACS Catal. 7, 5500-5512 (2017).
18. Carrillo, P., Shi, R., Teeluck, K., Senanayake, S. D. \& White, M. G. In situ formation of FeRh nanoalloys for oxygenate synthesis. ACS Catal. 8, 7279-7286 (2018)

19. Lin, T. et al. Direct production of higher oxygenates by syngas conversion over a multifunctional catalyst. Angew. Chem. Int. Ed. 58, 4627-4631 (2019).

20. Haynes, A. Catalytic methanol carbonylation. Adv. Catal. 53, 1-45 (2010)

21. Cheung, P., Bhan, A., Sunley, G. J. \& Iglesia, E. Selective carbonylation of dimethyl ether to methyl acetate catalysed by acidic zeolites. Angew. Chem. Int. Ed. 45, 1617-1620 (2006).

22. Climent, M. J., Corma, A., Iborra, S. \& Sabater, M. J. Heterogeneous catalysis for tandem reactions. ACS Catal. 4, 870-891 (2014).

23. Lohr, T. L. \& Marks, T. J. Orthogonal tandem catalysis. Nat. Chem. 7, 477-482 (2015).

24. Yamada, Y. et al. Nanocrystal bilayer for tandem catalysis. Nat. Chem. 3, 372-376 (2011).

25. Huff, C. A. \& Sanford, M. S. Cascade catalysis for the homogeneous hydrogenation of $\mathrm{CO}_{2}$ to methanol. J. Am. Chem. Soc. 133, 18122-18125 (2011).

26. Jiao, F. et al. Selective conversion of syngas to light olefins. Science 351, 1065-1068 (2016).

27. Cheng, K. et al. Direct and highly selective conversion of synthesis gas into lower olefins: design of a bifunctional catalyst combining methanol synthesis and carbon-carbon coupling. Angew. Chem. Int. Ed. 55, 4725-4728 (2016).

28. Cheng, K. et al. Bifunctional catalysts for one-step conversion of syngas into aromatics with excellent selectivity and stability. Chem 3, 334-347 (2017).

29. Jiao, F. et al. Shape-selective zeolites promote ethylene formation from syngas via a ketene intermediate. Angew. Chem. Int. Ed. 57, 4692-4696 (2018).

30. Liu, X. et al. Design of efficient bifunctional catalysts for direct conversion of syngas into lower olefins via methanol/dimethyl ether intermediates. Chem. Sci. 9, 4708-4718 (2018).

31. Zhou, W. et al. Direct conversion of syngas into methyl acetate, ethanol, and ethylene by relay catalysis via the intermediate dimethyl ether. Angew. Chem. Int. Ed. 57, 12012-12016 (2018).

32. Zhang, Y. et al. Intermediate product regulation over tandem catalysts for onepass conversion of syngas to ethanol. Catal. Sci. Technol. 9, 1581-1594 (2019).

33. Li, X. et al. Direct synthesis of ethanol from dimethyl ether and syngas over combined $\mathrm{H}$-mordenite and $\mathrm{Cu} / \mathrm{ZnO}$ catalysts. ChemSusChem 3, 1192-1199 (2010).

34. Yang, G. et al. A new method of ethanol synthesis from dimethyl ether and syngas in a sequential dual bed reactor with the modified zeolite and $\mathrm{Cu} / \mathrm{ZnO}$ catalysts. Catal. Today 164, 425-428 (2011).

35. Gao, X. et al. Designing a novel dual bed reactor to realize efficient ethanol synthesis from dimethyl ether and syngas. Catal. Sci. Technol. 8, 2087-2097 (2018).

36. Ni, Y. et al. A green route for methanol carbonylation. Catal. Sci. Technol. 7, 4818-4822 (2017).

37. Rachmady, W. \& Vannice, M. A. Acetic acid hydrogenation over supported platinum catalysts. J. Catal. 192, 322-334 (2000).

38. Sun, J. et al. Direct conversion of syngas into light olefins over zirconiumdoped indium (II) oxide and SAPO-34 bifunctional catalysts: design of oxide component and construction of reaction network. ChemCatChem 10, 1536-1541 (2018).

39. Tian, P., Wei, Y., Ye, M. \& Liu, Z. Methanol to olefins (MTO): from fundamentals to commercialization. ACS Catal. 5, 1922-1938 (2015).

40. Olsbye, U. et al. Conversion of methanol to hydrocarbons: how zeolite cavity and pore size controls product selectivity. Angew. Chem. Int. Ed. 51, 5810-5831 (2012).

41. Boronat, M., Martínez-Sánchez, C., Law, D. \& Corma, A. Enzyme-like specificity in zeolites: a unique site position in mordenite for selective carbonylation of methanol and dimethyl ether with CO. J. Am. Chem. Soc. 130, 16316-16323 (2008).

42. Liu, J., Xue, H., Huang, X., Li, Y. \& Shen, W. Dimethyl ether carbonylation to methyl acetate over HZSM-35. Catal. Lett. 139, 33-37 (2010).

43. Xue, H., Huang, X., Zhan, E., Ma, M. \& Shen, W. Selective dealumination of mordenite for enhancing its stability in dimethyl ether carbonylation. Catal. Commun. 37, 75-79 (2013).

44. Wang, J. et al. A highly selective and stable $\mathrm{ZnO}-\mathrm{ZrO}_{2}$ solid solution catalyst for $\mathrm{CO}_{2}$ hydrogenation to methanol. Sci. Adv. 3, el701290 (2017).

45. Silver, R. G., Hou, C. J. \& Ekerdt, J. G. The role of lattice anion vacancies in the activation of $\mathrm{CO}$ and as the catalytic site for methanol synthesis over zirconium dioxide and yttria-doped zirconium dioxide. J. Catal. 118, 400-416 (1989).

46. Zhou, C. et al. Highly active $\mathrm{ZnO}-\mathrm{ZrO}_{2}$ aerogels integrated with H-ZSM-5 for aromatics synthesis from carbon dioxide. ACS Catal. 10, 302-310 (2020).

47. Razdan, N. K., Kumar, A. \& Bhan, A. Controlling kinetic and diffusive lengthscales during absorptive hydrogen removal in methane dehydroaromatization on $\mathrm{MoC}_{x} / \mathrm{H}-\mathrm{ZSM}-5$ catalysts. J. Catal. 372, 370-381 (2019). 
48. Hunger, M., Sarv, P. \& Samoson, A. Two-dimensional triple-quantum ${ }^{23} \mathrm{Na}$ MAS NMR spectroscopy of sodium cations in dehydrated zeolites. Solid State Nucl. Magn. Reson. 9, 115-120 (1997).

49. Deng, F., Yue, Y. \& Ye, C. ${ }^{1} \mathrm{H} /{ }^{27} \mathrm{Al}$ TRAPDOR NMR studies on aluminum species in dealuminated zeolites. Solid State Nucl. Magn. Reson. 10, 151-160 (1998).

50. Hayashi, S. \& Kojima, N. Acid properties of H-type mordenite studied by solid-state NMR. Micropor. Mesopor. Mat. 141, 49-55 (2011).

51. Lukyanov, D. B., Vazhnova, T., Cherkasov, N., Casci, J. L. \& Birtill, J. J Insights into Brønsted acid sites in the zeolite mordenite. J. Phys. Chem. C. 118, 23918-23929 (2014).

52. Cherkasov, N., Vazhnova, T. \& Lukyanov, D. B. Quantitative infra-red studies of Brønsted acid sites in zeolites: case study of the zeolite mordenite. Vib. Spectrosc. 83, 170-179 (2016).

53. Bera, $\mathrm{P}$. et al. Ionic dispersion of $\mathrm{Pt}$ over $\mathrm{CeO}_{2}$ by the combustion method: structural investigation by XRD, TEM, XPS, and EXAFS. Chem. Mater. 15, 2049-2060 (2003).

54. de Miguel, S. R. et al. Characterization of bimetallic PtSn catalysts supported on purified and $\mathrm{H}_{2} \mathrm{O}_{2}$-functionalized carbons used for hydrogenation reactions. J. Catal. 184, 514-525 (1999).

55. Cheng, Z. et al. Deactivation kinetics for the carbonylation of dimethyl ether to methyl acetate on H-MOR. Ind. Eng. Chem. Res. 56, 13618-13627 (2017).

56. Weisz, P. B. Polyfunctional heterogeneous catalysis. Adv. Catal. 13, 137-190 (1962).

57. Zečević, J., Vanbutsele, G., de Jong, K. P. \& Martens, J. A. Nanoscale intimacy in bifunctional catalysts for selective conversion of hydrocarbons. Nature $\mathbf{5 2 8}$ 245-248 (2015).

58. Gao, P. et al. Direct conversion of $\mathrm{CO}_{2}$ into liquid fuels with high selectivity over a bifunctional catalyst. Nat. Chem. 9, 1019-1024 (2017).

59. García-Herreros, P., Gómez, J. M., Gil, I. D. \& Rodríguez, G. Optimization of the design and operation of an extractive distillation system for the production of fuel grade ethanol using glycerol as entrainer. Ind. Eng. Chem. Res. 50, 3977-3985 (2011).

60. Li, Q. et al. High efficient water/ethanol separation by a mixed matrix membrane incorporating MOF filler with high water adsorption capacity. $J$ Membr. Sci. 544, 68-78 (2017).

61. Fang, C., Wu, H., Lee, S. Y., Mahajan, R. L. \& Qiao, R. The ionized graphene oxide membranes for water-ethanol separation. Carbon 136, 262-269 (2018).

62. Liu, X. et al. Selective transformation of carbon dioxide into lower olefins with a bifunctional catalyst composed of $\mathrm{ZnGa}_{2} \mathrm{O}_{4}$ and SAPO-34. Chem. Commun. 54, 140-143 (2018).

63. Zhang, P., Tan, L., Yang, G. \& Tsubaki, N. One-pass selective conversion of syngas to para-xylene. Chem. Sci. 8, 7941-7946 (2017).

\section{Acknowledgements}

This work was supported by the National Key Research and Development Program of the Ministry of Science and Technology of China (No. 2017YFB0602201) and the
National Natural Science Foundation of China (Nos. 91945301, 91545203, 21972116, 21433008, 21872112, 21673188 and 21690082). We acknowledge Prof. L. Peng and Y. Wen (Nanjing University, China) for performing NMR characterizations.

\section{Author contributions}

J.K. and S.H. performed experiments for syntheses of catalysts and catalytic reactions, and analysed the experimental results. J.K. also co-wrote the paper. W.Z. performed most of the catalyst characterisations and analysed the characterisation results. Z.S. conducted the catalyst stability test. Y.L. and M.C. conducted FT-IR and XPS characterisations. Q.Z. analysed all the data and co-wrote the paper. Y.W. designed and guided the study, and co-wrote the paper. All of the authors discussed the results and reviewed the paper.

\section{Competing interests}

The authors declare no competing interests.

\section{Additional information}

Supplementary information is available for this paper at https://doi.org/10.1038/s41467 020-14672-8.

Correspondence and requests for materials should be addressed to Q.Z. or Y.W.

Peer review information Nature Communications thanks Freek Kapteijn and the other, anonymous, reviewer(s) for their contribution to the peer review of this work. Peer reviewer reports are available.

Reprints and permission information is available at http://www.nature.com/reprints

Publisher's note Springer Nature remains neutral with regard to jurisdictional claims in published maps and institutional affiliations.

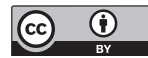

Open Access This article is licensed under a Creative Commons Attribution 4.0 International License, which permits use, sharing, adaptation, distribution and reproduction in any medium or format, as long as you give appropriate credit to the original author(s) and the source, provide a link to the Creative Commons license, and indicate if changes were made. The images or other third party material in this article are included in the article's Creative Commons license, unless indicated otherwise in a credit line to the material. If material is not included in the article's Creative Commons license and your intended use is not permitted by statutory regulation or exceeds the permitted use, you will need to obtain permission directly from the copyright holder. To view a copy of this license, visit http://creativecommons.org/ licenses/by/4.0/.

(C) The Author(s) 2020 